Review

\title{
Support with mechanical vibrations of welding processes - review of own research
}

\author{
Arkadiusz Krajewski *(D), Paweł Kołodziejczak (), Paweł Cegielski ํ), Jarosław Grześ \\ Warsaw University of Technology, Faculty of Mechanical and Industrial Engineering, Warsaw, Poland; \\ arkadiusz.krajewski@pw.edu.pl (A.K.); pawel.kolodziejczak@pw.edu.pl (P.K.); \\ pawel.cegielski@pw.edu.pl (P.C.); jaroslaw.grzes@pw.edu.pl (J.G.); \\ * Correspondence: arkadiusz.krajewski@pw.edu.pl (A.K.)
}

Received: 10.05.2021; Accepted: 01.06.2021

\begin{abstract}
The article discusses the most important original achievements in the use of high-power mechanical vibrations with low and ultrasonic frequency in various welding processes such as (131) MIG, (135) MAG, (141) TIG, (21) RW, (522) LW, (45) diffusion welding and (924) brazing in relation to various basic materials such as structural steel and aluminum alloys. Mechanical vibrations were introduced by means of ultrasonic vibrating systems and using the shot-blasting process, as well as acoustic influence. As part of the comparative research, the structure and hardness analysis of HV0.1 was presented. The obtained results indicate that both low-frequency and ultrasonic frequency vibrations significantly change the properties of the resulting structures affected by mechanical vibrations. The scale of these changes varies depending on the frequency and parameters specific to each of the welding processes used. The obtained results allow us to conclude that the skilful application of mechanical vibrations accompanying welding processes can contribute to the reduction of grain sizes, to change the depth or width of penetration and to lowering hardness in the sensitive heat affected zone area.
\end{abstract}

Key words: mechanical vibration; ultrasonic and acoustic; shoot-blasting; MIG, MAG, TIG, LW, RW

\section{Introduction}

The inspiration for the study of the effects of mechanical vibrations introduced simultaneously with the bonding processes were the works carried out on diffusion welding [1], soldering alumina ceramics with steel [2], resistance welding [3,4], and classic welding processes, which began to be published in greater numbers at the turn of the 1990s and 2000s [5-8].

The available literature in the field of the impact of mechanical vibrations during welding processes report that their proper use leads to an improvement in the structure of welded joints understood as a reduction in grain size, geometric metamorphosis leading to equiaxial grains and a change in the number and proportion of some phases formed in the structure [9]. Moreover, it is known that the areas to be melted, those close to the fusion line, and the heat affected zone itself, change to a different extent. In general, it can be said that welding processes carried out with a controlled share of mechanical vibrations allow to improve the structure of the obtained welded joints or padding welds. In many cases, however, the use of vibrations becomes a source of technical complications related to the need to use complex vibrating systems, vibration generators, etc. The proximity of the vibration source and the molten metal pool is also a significant problem, which causes the risk of damaging the vibrating system. The vast majority of methods of introducing mechanical vibrations known from the literature require perfect contact of the elements of the vibrating system with the base material [6]. There are studies [6,9] in which the authors mention that the mechanical vibrations were delivered to the welding zone, but they do not provide information on the method of mounting the base material and contact with the vibrating system. Taking into account that mechanical vibrations are able to improve the structure of welded joints or padding welds enough to constitute an alternative to heat treatment, it is worth considering the use of vibrations while eliminating the technical problems associated with their application. Apart from the vibrating systems that require permanent and secure mounting and contact with the basic material, preliminary results of tests with the introduction of vibrations that do not require rigid mounting of the vibrating system to the basic material have been proposed and discussed. Vibrations can be introduced as a result of supplying the energy of impact with the ground of the shot (metallic particles with a shape similar to a sphere) or transmitting vibration energy of gas particles, i.e. acoustic vibrations. The effect you get will 
depend on many factors. Among them, the basic ones should be mentioned: power or energy of vibrations, path, medium and direction of its transmission, position of the vibration source depending on the place of influence of the welding heat source. The article presents the cross-sectional impact of various methods of introducing mechanical vibrations to various basic materials. Comparative results of metallographic tests revealing basic differences in the structural structure of obtained joints or padding welds are presented. The results of research on the mechanical properties of the basic areas of the obtained structures are also included. The results of many years of own research show that the application of mechanical vibrations can be effective both in the case of using various methods of bonding and in the case of many types of solid and liquid bonded materials. Many possibilities of introducing vibrations have been shown. Some require a secure attachment to effectively transfer the energy of variable-phase vibrations, others allow the use of stochastic vibrations with averaged spectrum, which can accompany moving welding heat sources, thus ensuring fixed and reproducible effects regardless of the location of the heat source. The condition for achieving the desired effect is knowledge about the form, direction and method of transmission of the energy of mechanical vibrations.

\section{Diffusion welding of copper with the participation of longitudinal ultrasonic vibrations}

One of the first experiments carried out at the Department of Welding Engineering of the Warsaw University of Technology in the early 1990s consisted in introducing longitudinal ultrasonic vibrations into the diffusion-welded MOOB copper cylindrical elements [1]. As a result, joints were obtained at a lower temperature than by welding without vibrations, and characterized by similar strength of the joint. It turned out that the greatest impact of ultrasonic vibrations on the strength properties occurs at a lower welding temperature $(823 \div 973 \mathrm{~K})$. The test results showed that the process temperature can be reduced by approx. $100 \mathrm{~K}$ in relation to the traditional welding method and a welded joint with comparable connection strength can be obtained. It also turned out that above $973 \mathrm{~K}$ the degree of impact of vibrations decreases with increasing temperature. The tensile strength test results for copper-copper joints welded by diffusion at a temperature of $973 \mathrm{~K}$ at a pressure of $5 \mathrm{MPa}$, a time of $1200 \mathrm{~s}$ and a vacuum of $1.33 \times 10^{-3} \mathrm{~Pa}$ are shown in Figure 1a. The structure of a diffusion welded joint with the use of vibrations is shown in Figure $1 \mathrm{~b}$.

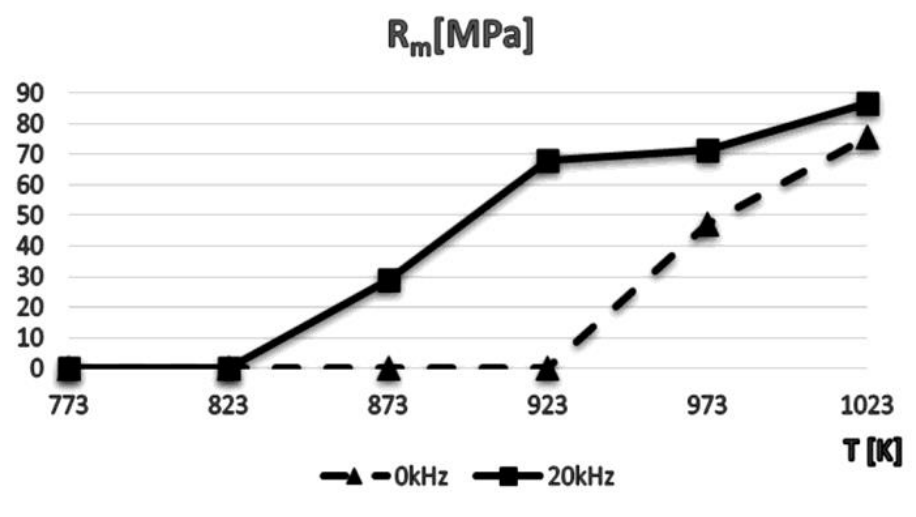

(a)

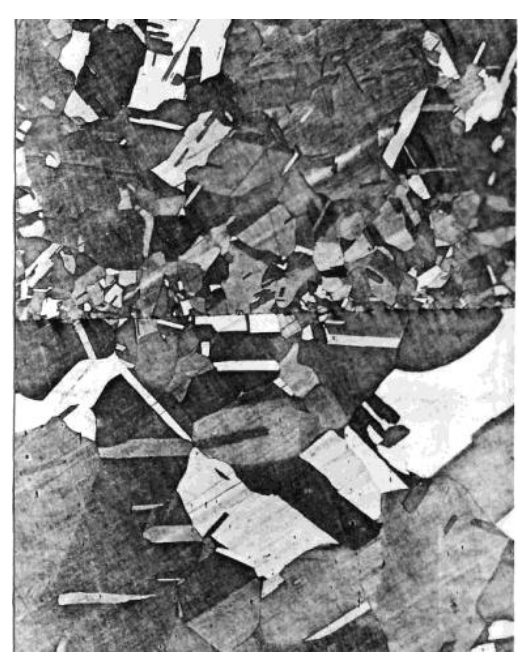

(b)

Fig. 1. MOOB copper diffusion welding: a) tensile strength results; b) structure of the area of the diffusion welded joint with the participation of vibrations with a frequency of $20 \mathrm{kHz}$ (longitudinal vibrations introduced from the top)

\section{Brazing of alumina ceramics with stainless steel with the assistance of ultrasonic vibrations}

In the mid-1990s, research was conducted on brazing alumina ceramics with metals. When brazing $\mathrm{Al}_{2} \mathrm{O}_{3}$ ceramics with steel or other metallic materials, microcracks in the ceramic material often appeared. This was also confirmed by [3,6]. Therefore, an attempt was made to introduce longitudinal ultrasonic vibrations into the ceramic material in the brazing process with 1.4541 (1H18N9T) steel [2]. In order to allow the vibrations to pass between the elements to be bonded, adequate pressure had to be applied, which is not a normal practice during brazing. This procedure allowed for the effective introduction of 
vibrations and obtaining brazed joints without microcracks in the ceramics and an increase in the strength in the bending test in relation to joints obtained without vibrations by approx. $40 \%$. The process of brazing with silver CB1 solders by Degussa of the corundum ceramics with a purity of $98 \%$ was carried out under a pressure of $28 \mathrm{MPa}$, in a vacuum of $2.6 \times 10^{-3} \mathrm{~Pa}$ and at a temperature of $1003 \div 1223 \mathrm{~K}$ for $300 \mathrm{~s}$. Ultrasonic vibrations were introduced using a GU $21 \div 250$ generator with a power of $250 \mathrm{~W}$ and a frequency of $20 \mathrm{kHz}$.

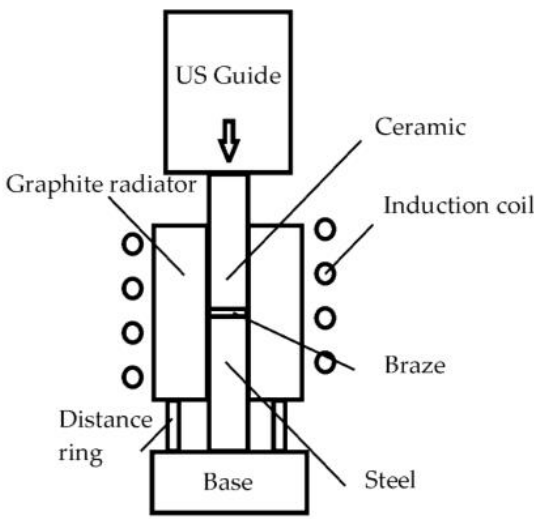

(a)

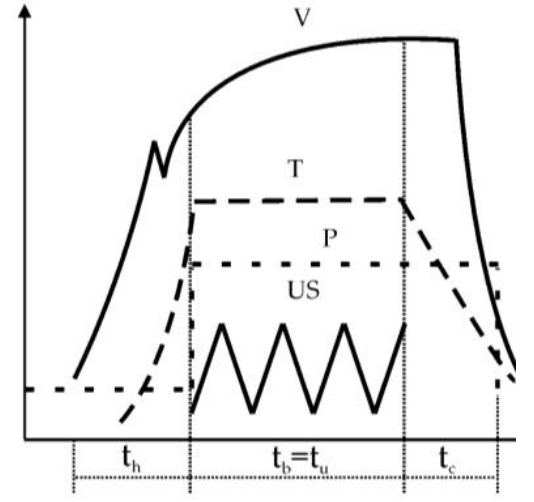

(b)

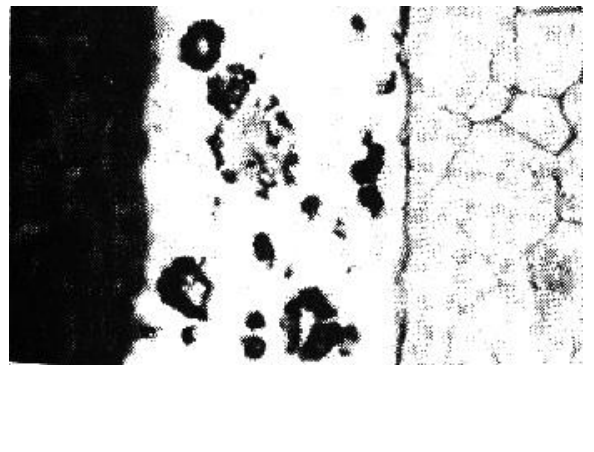

(c)

Fig. 2. Brazing conditions: a) setup in the vacuum chamber of the UZD01 device; b) the bonding process cycle; $t_{h}$ - heating time, $t_{z}=t_{u}$ - bonding time equal to the vibration application time, $t_{c}-$ cooling time, $T-$ temperature, $\mathrm{V}$ - vacuum, P - pressure, US - application of ultrasonic vibrations; c) microstructure of a brazed joint at $1013 \mathrm{~K}$ temperature, bending strength $81 \mathrm{MPa}$ (from the left: ceramic, CB1 filler metal, steel 1.4541, mag. 200x)

\section{Resistance welding with ultrasonic vibrations}

In the first decade of the 2000s, longitudinal ultrasonic vibrations were used in a specific pulsed resistance welding system. In this bonding process, it resulted in qualitatively different effects than in the case of bonding with the use of welding with remelting [3,4]. In the experiment, the MICROWELDER GM-3450 impulse resistance micro-welding device was used, in which the pressure is exerted through a moving working electrode, and the welding process is carried out as a result of discharging the capacitor bank in the device. Ultrasonic vibrations with a frequency of $20 \mathrm{kHz}$ were introduced by means of a system consisting of a GUZ 20 ultrasonic generator with a power of $2.5 \mathrm{~kW}$, a cylindrical waveguide made of steel 1.0503 (45) with a single wavelength, on which a $0.15 \mathrm{~mm}$ thick foil of steel 1.4541 (1H18N9T) was welded. The test stand is shown in Figure 3. The welding experiments were performed both with and without ultrasonic vibrations on the waveguide forehead.

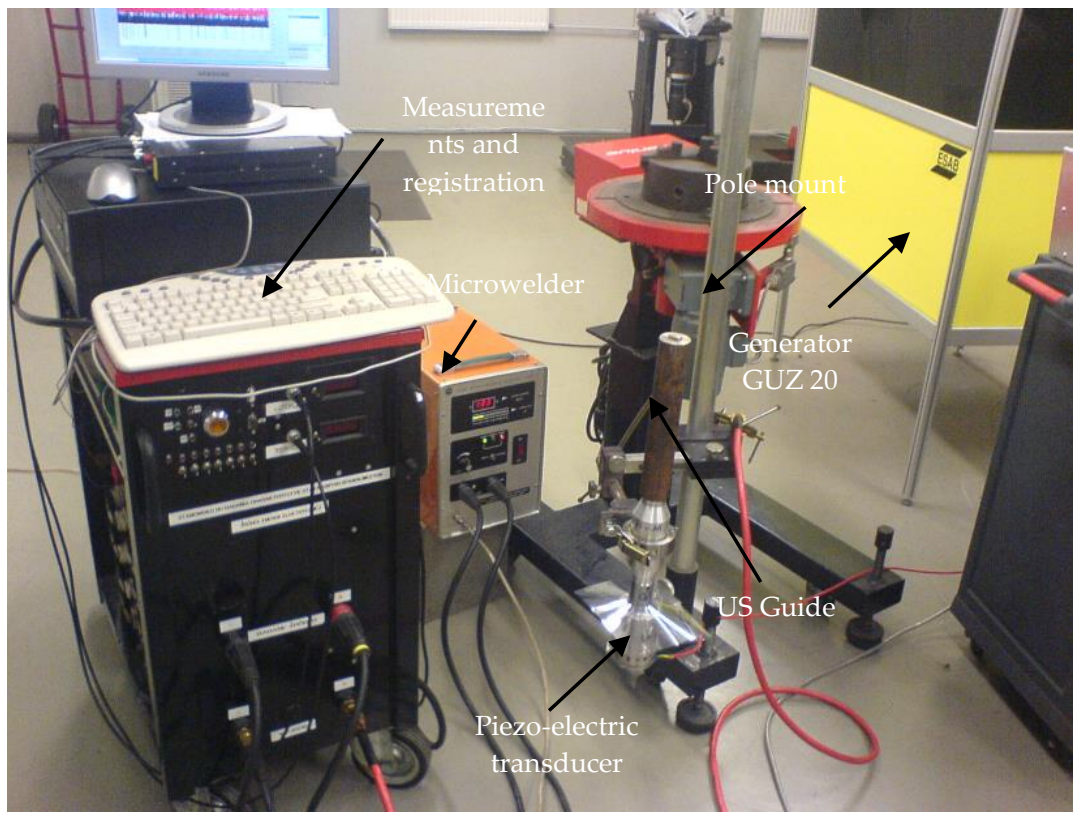

(a)

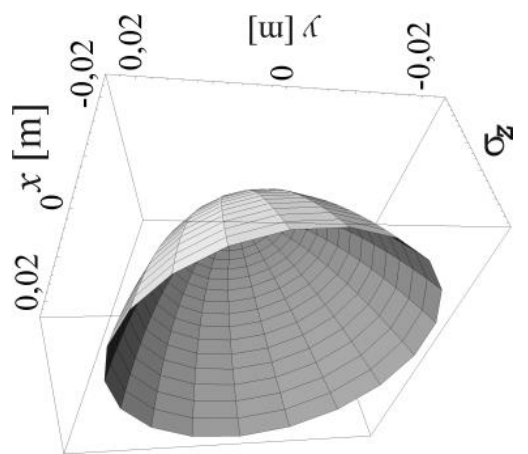

(b)

Fig. 3. Experimental set-up for impulse resistance micro-welding with the application of ultrasonic vibrations (a); distribution of equivalent stresses on the waveguide forehead $(b)$ 
Figure 4 shows the microstructure of the welds obtained near the welding line of the 1.0503 steel substrate and 1.4541 foil. The hardness distribution in the weld and in the transition zone is shown in Figure 5. Each measuring point is the average of four measurements.

The use of ultrasonic vibrations during pulse resistance welding had little effect on changes in the structure, although a greater number and fragmentation of perlite areas in 1.0503 steel can be noticed. As a result of the application of vibrations, a slight increase in hardness is observed in the transition zone between the applied foil and the substrate, while in the weld itself, the hardness decreases. The benefits of introducing vibrations in this case are visible only in the weld core.

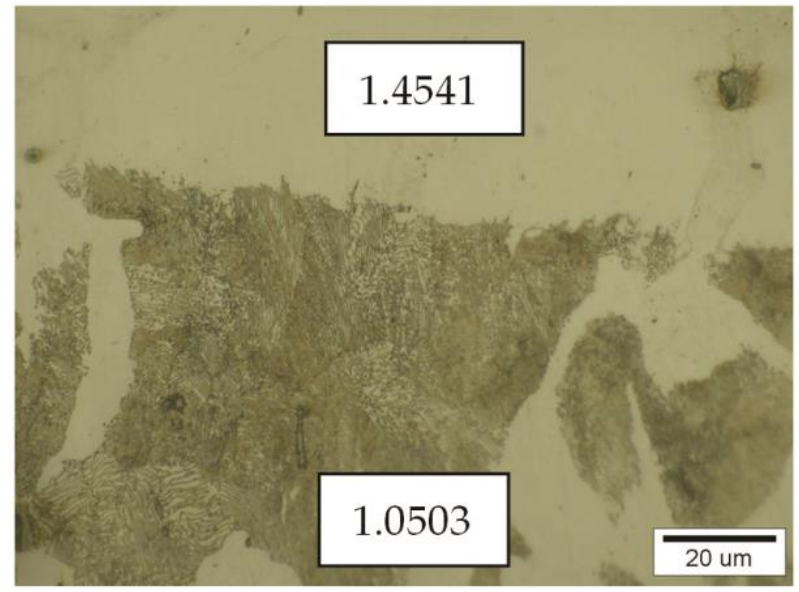

(a)

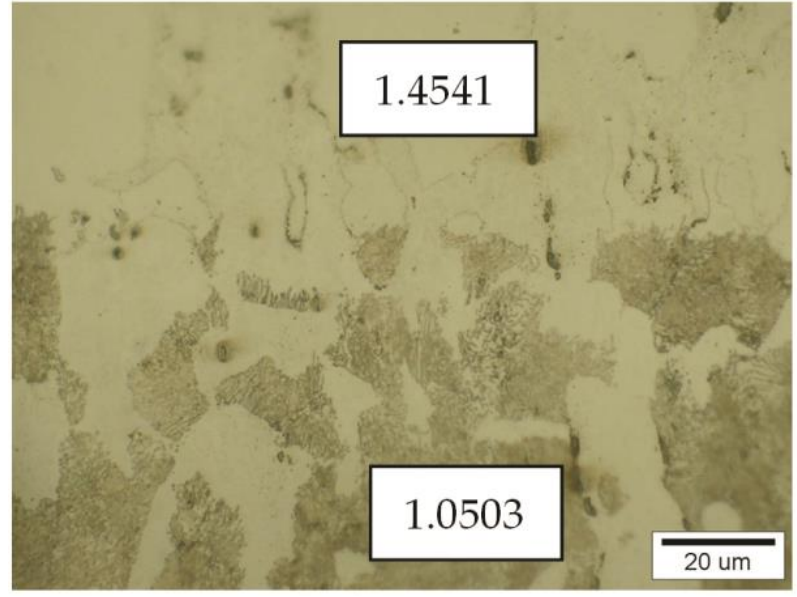

(b)

Fig. 4. Weld obtained at $\mathrm{U}=450 \mathrm{~V}$ without ultrasound (a) and with ultrasound (b)

(a)

Fig. 5. Results of HV0.1 microhardness measurement in the weld area a) and in the transition zone. Measurement points 1, 2 and 3 mark a straight line perpendicular to the axis of the electrodes

\section{MMA surfacing with the participation of low frequency mechanical vibrations}

When using mechanical vibrations with ultrasonic frequency, the question was asked whether a lower frequency and higher amplitude could bring any benefits to the structure of the crystallizing pool of greater volume and mass. In order to obtain an answer to this question, an experiment was performed consisting in introducing into the surfacing zone mechanical vibrations with a frequency of approx. $50 \mathrm{~Hz}$ and an amplitude of approx. $0.5 \mathrm{~mm}$, introduced parallel to the axis of the padding weld laid on the substrate made of S235JR steel [4]. The calculated wavelength has a value of about $96 \mathrm{~m}$, which additionally brings independence from the relation of the obtained effects depending on the distance from the source of vibrations. It can therefore be assumed that the surfacing was carried out in the so-called "Arrow", i.e. in the place of the highest value of the vibration amplitude. The nature of the equivalent stress distribution generated in this case is similar to that shown in Figure 6a. The surfacing test was carried out according to the diagram in Figure $6 b$.

The surfacing process was carried out on two identical sheets made of S235JR steel, $8 \mathrm{~mm}$ thick, $50 \mathrm{~mm}$ wide and $100 \mathrm{~mm}$ long. One of the samples was surfaced with vibrations with a frequency of $50 \mathrm{~Hz}$, energy of approx. $4 \mathrm{~J}$ and acceleration $\mathrm{a}=3.5 \mathrm{~m} / \mathrm{s}^{2}$, produced by an impact device. The second one was surfaced without their participation. The surfacing tests were performed manually with an ESAB OK 50.40 
coated electrode with a diameter of $2.5 \mathrm{~mm}$. The welding current intensity was $100 \mathrm{~A}$. The planes of the microsections made in the case of padding welds laid without vibrations (Fig. 6c) and those to which they were introduced (Fig. 6d) are parallel to each other.

The use of low-frequency vibrations resulted in grain refinement in the padding weld. In addition, much finer and shorter pearlite precipitates can be seen in the sample surfaced with vibrations. The obtained effect on the microstructural structure can be generally considered favorable, which should undoubtedly improve the mechanical properties of the obtained padding welds, although they have not been tested.

\section{MMA surfacing with the participation of ultrasonic mechanical vibrations}

In order to compare the effect of low-frequency vibrations and ultrasonic frequencies, MMA welding was carried out on sheets of non-alloy steel S235JR with a thickness of $8 \mathrm{~mm}$ and dimensions of $140 \times 50 \mathrm{~mm}$, carried out manually using a coated electrode with a diameter of $2.5 \mathrm{~mm}$ OK 50.40 by ESAB [4]. The welding current intensity was $100 \mathrm{~A}$. The samples were immersed in the water filling the ultrasonic bath to a level slightly less than their thickness. Due to the free rest of the sample in the washer, the nature of the displacements due to vibrations could slightly differ from what would have happened with its unilateral fixation (Fig. 7a). The padding welds were laid in a flat position over a section with a length of approx. $60 \mathrm{~mm}$ without vibrations and by introducing vibrations with a frequency of $20 \mathrm{kHz}$ from the water, from the side of the ridge according to the diagram shown in Figure $7 \mathrm{~b}$. Comparing the photos in Figures $7 \mathrm{c}$ and $7 \mathrm{~d}$, one can notice a significant difference between the structure of the center of the padding weld obtained after welding with the use of ultrasonic vibrations, compared to the one obtained without their participation. The introduced vibrations disrupted the ferrite mesh and led to the refinement of the grain structure in the padding weld.

As a result of introducing ultrasonic vibrations through the water layer, the structure was more homogenized and the grain size in the padding weld was reduced. The quantitative analysis of the microstructure of the obtained padding welds, carried out with the MULTI SCAN BASE software, revealed that the share of darker areas in the total structure of the padding weld for the padding weld laid with the use of vibrations was approx. $30 \%$. In the case of the padding weld obtained without vibration, it was found that the share of analogous areas is $35 \%$.

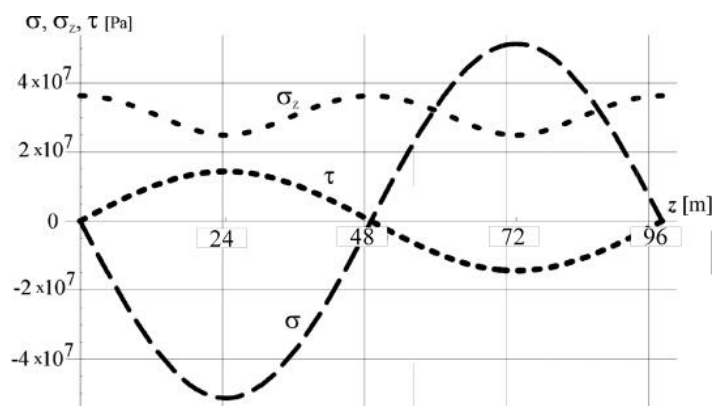

(a)

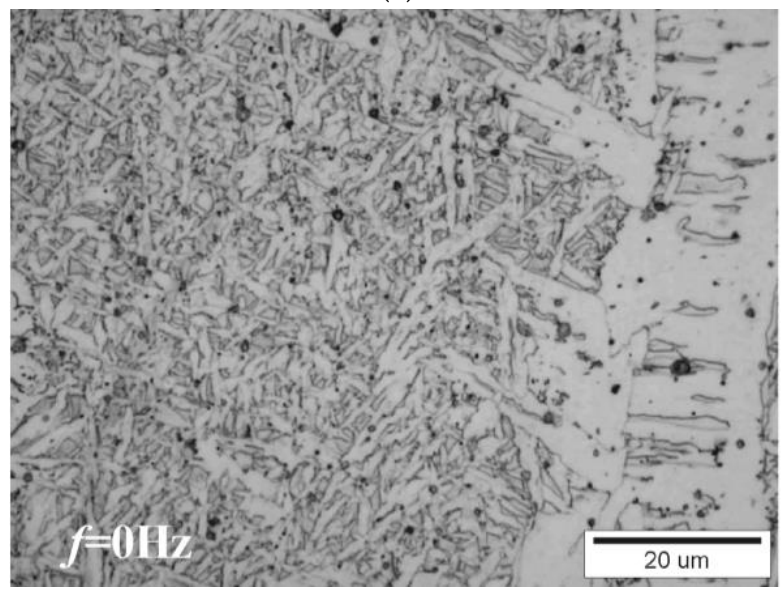

(c)

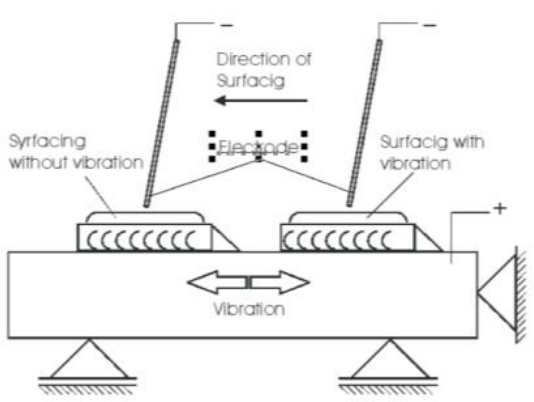

(b)

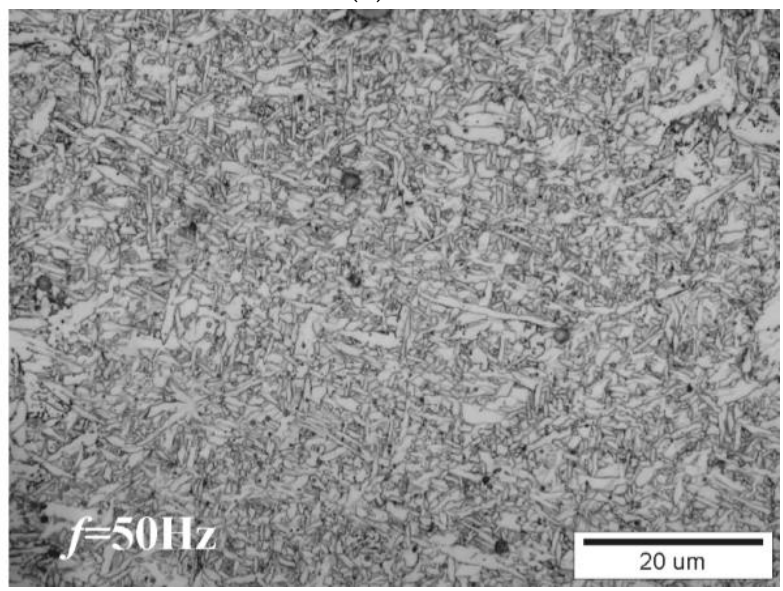

(d)

Fig. 6. Distribution of axial stresses $\sigma$, transverse $\tau$ and reduced stresses $\sigma z$ in steel S235JR (a); surfacing process idea (b); center structure of the weld obtained without vibrations (c); microstructure of the weld center with vibrations of $50 \mathrm{~Hz}$ 


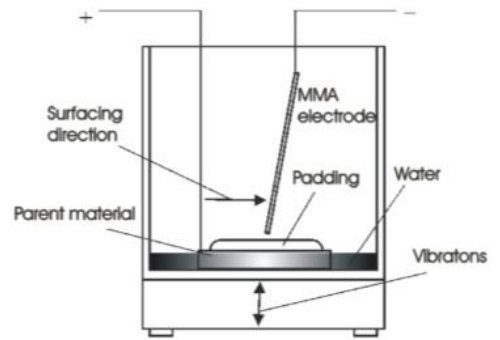

(a)

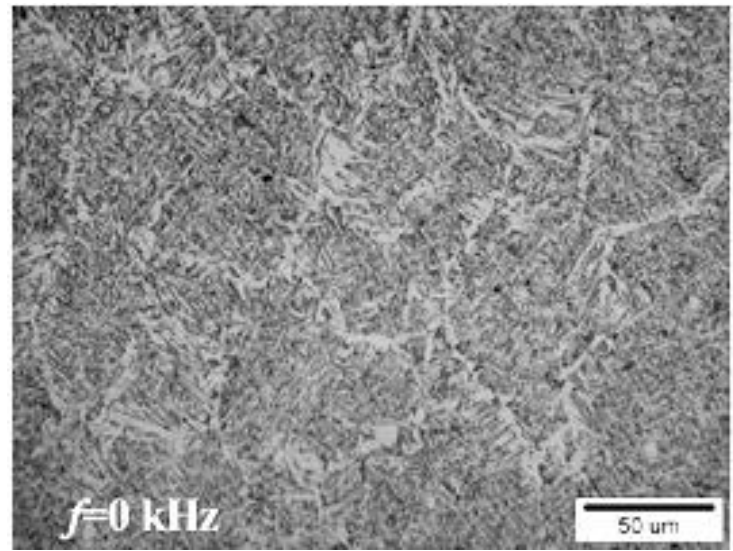

(c) (b)

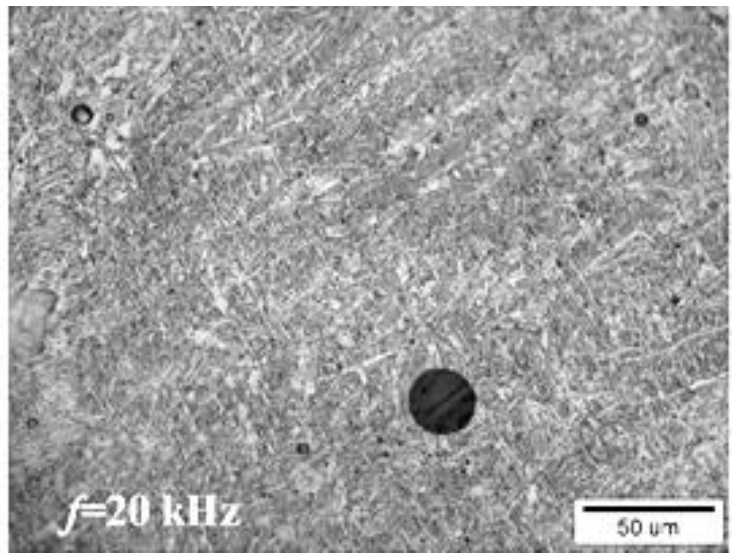

(d)

Fig. 7. Distribution of displacements due to vibrations introduced to the sample through the vibrating transducer of the ultrasonic cleaner (a); surfacing process set-up (b); the structure of the weld obtained without vibrations (c); the structure of the weld obtained under the influence of ultrasonic vibrations

\section{TIG remelting on a forming waveguide made of 2017A aluminum alloy}

Based on the own research [10-15], it was shown that the phase of the vibrations introduced into the welded object may determine the desired or unfavorable microstructural changes in a specific joint zone. In another experiment, an attempt was made to determine the effect of ultrasonic vibrations in a specific phase on the joint penetrations and padding welds laid using the TIG method along the forming waveguide. The experiments were carried out on a cylinder-shaped aluminum alloy 2017A waveguide with a diameter of $0.045 \mathrm{~m}$ and a length of $0.254 \mathrm{~m}$. The length of the waveguide was determined to obtain a waveguide with a single wave of expansion vibrations $\lambda$, the frequency of which was $20 \mathrm{kHz}$ and the amplitude approx. $10 \mu \mathrm{m}$. The nature of the impact of vibrations in such a system is shown in Figure 5a. The experimental stand is shown in Figure 8a. The stress distribution from vibrations is shown in Figure $8 \mathrm{~b}$. The pool of molten metal was protected with argon, the flow of which was $11 \mathrm{dm}^{3} / \mathrm{min}$. An alternating current with a frequency of $30 \mathrm{~Hz}$ and a value of $100 \mathrm{~A}$ was used for fusing. Figure 9 shows pictures of the weld face obtained by the TIG AC method with and without ultrasonic vibrations. In the case of joint penetration obtained without the use of vibrations (Fig. 9a-b), it can be seen that there is open porosity locally, and the face surface is uniform, flat. In the longitudinal axis of the face, a lighter area can be seen that differs from the external areas of the joint penetration. Figure $9 \mathrm{c}$ shows the face of the fusion obtained at the location of the vibration arrow at a distance of $0.127 \mathrm{~m}$ from the beginning of the waveguide. There are wavy unevenness and surface oxidation. The surface of the waveguide adjacent to the face shows characteristic "scorching" indicative of the instability of the argon gas shield.

At a distance of $0.1905 \mathrm{~m}$ from the fixed waveguide forehead, i.e. in the vibration node (Fig. 9d), it can be seen that there is no lighter area in the longitudinal axis of the face, as in the case of fusion in Figure 9c. The fusion face is wider, without oxidation and does not show such unevenness or porosity as in the other cases, and the fusion line is more even.

Figure 9 clearly shows the characteristic differences in the appearance and width of the face depending on the vibration phase. It can be noticed that in the "node" of vibrations (Figs. 9b and 9d) the face is even and the revealed unevenness of the face is fragmented and evenly distributed over the surface. The face obtained in the vibration "arrow" (Fig. 9c) clearly differs in quality from the other cases. You can see the oxidized surface and significant unevenness of the face. 


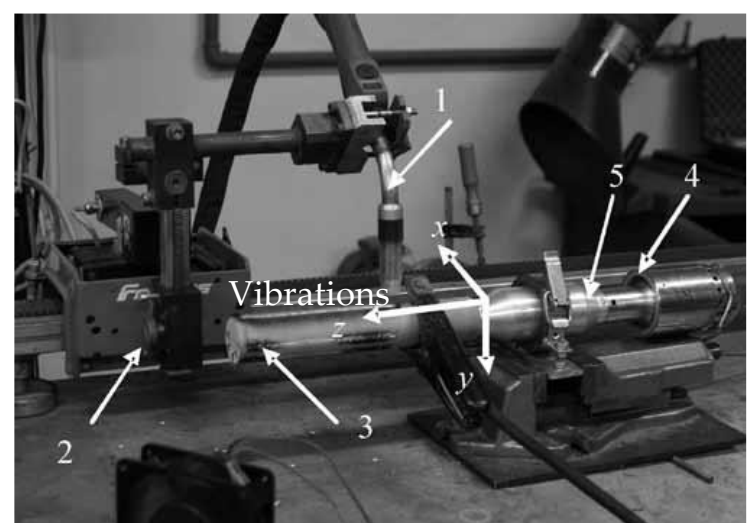

(a)

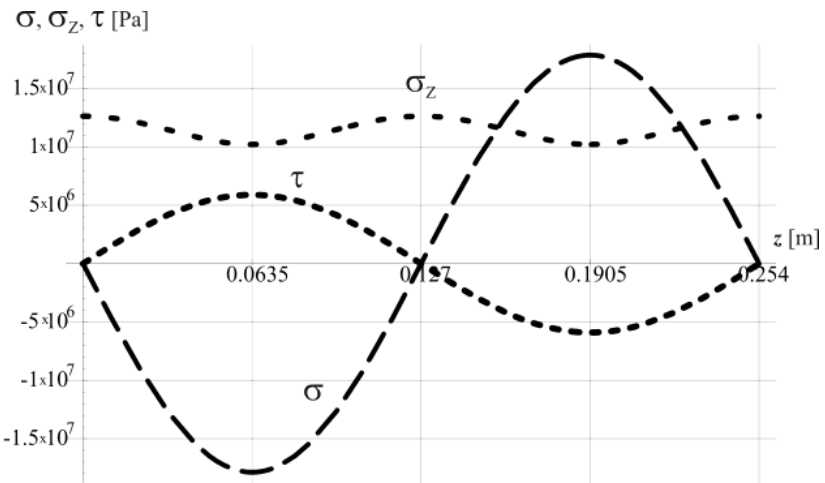

(b)

Fig. 8. The vibrating system used to investigate the dependence of the structure and properties of welds on the vibration phase (a): 1-welding holder, 2-positioner, 3-waveguide, 4-ultrasonic transducer, 5-concentrator with a gain of $1 / 1$; distribution of axial $\sigma$, transverse $\tau$ and reduced $\sigma$ stresses in the 2017A alloy waveguide (b)
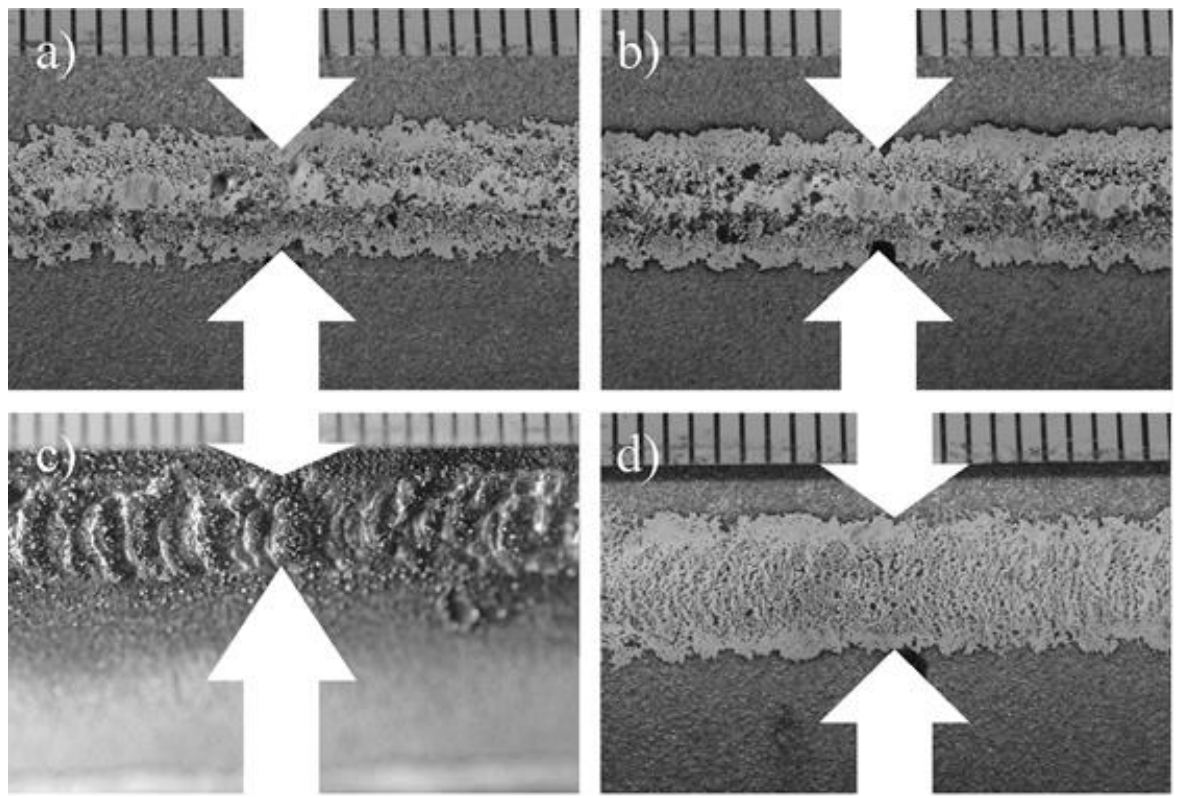

Fig. 9. View of the weld made by TIG AC method: (a) without vibrations in the area of $z=0.127 \mathrm{~m}$, (b) without vibrations in the area of $z=0.1905 \mathrm{~m}$, (c) with the use of ultrasonic vibrations in the area of $z=0.127 \mathrm{~m}(1 / 2 \lambda),(\mathrm{d})$ using ultrasonic vibrations in the area of $z=0.1905 \mathrm{~m}(3 / 4 \lambda)$ (visible plots in $\mathrm{mm}$, arrows indicate "arrows" and "node" vibrations)

More significant differences can be seen in Figure 10, which shows the structure of the characteristic cross-sectional areas of the fusion welds made by the TIG AC method. The fusion in Figure 10a, performed without ultrasonic vibrations, reveals a significant amount of gas bubbles. In Figure 10b, in the joint penetration made with the participation of vibrations, at a distance of $0.127 \mathrm{~m}$ (arrow) from the waveguide forehead, it can be seen that the face collapsed clearly. A homogeneous structure was revealed where the vibrations during remelting were in the "node" (Fig. 10c).

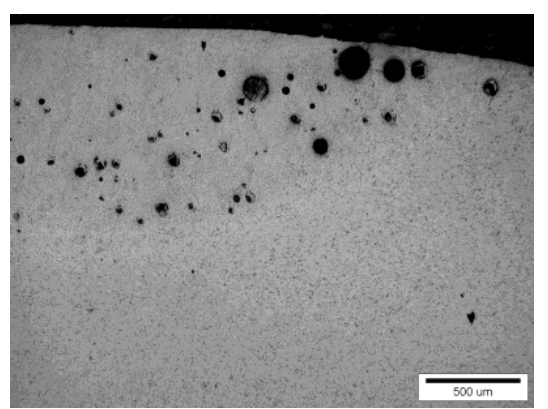

(a)

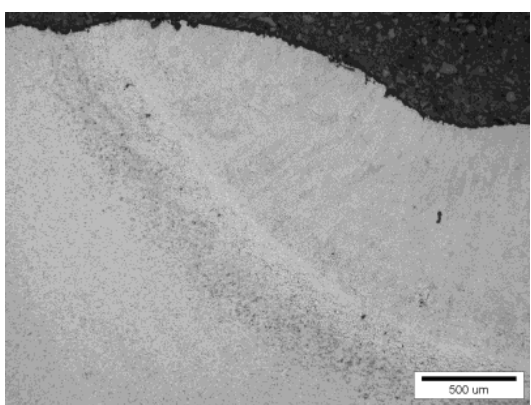

(b)

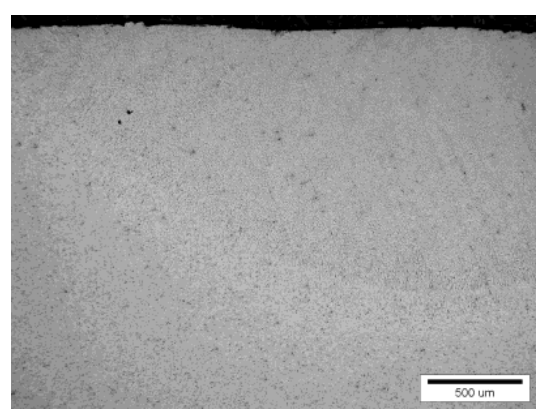

(c)

Fig. 10. Microstructure of weld made by TIG AC method: (a) without ultrasonic vibrations, (b) with the use of ultrasonic vibrations $z=0.127 \mathrm{~m}(1 / 2 \lambda)$, (c) with the use of ultrasonic vibrations $z=0.1905 \mathrm{~m}(3 / 4 \lambda)$ 


\section{MIG surfacing on a forming waveguide made of 2017A aluminum alloy}

Interesting results were obtained during the surfacing of 2017A aluminum alloy waveguide [15]. The surfacing experiments were carried out using the MIG method and the welds with a much larger crosssection were obtained (with a face width of approx. $6.5 \div 8.8 \mathrm{~mm}$ and a penetration depth of approx. $4 \div 5.3$ $\mathrm{mm}$ ). The volume of the liquid phase was in this case much larger than in the corresponding experiments with the use of the TIG method. For MIG surfacing, a wire made of 5056 aluminum alloy (AlMg5) with a diameter of $1.2 \mathrm{~mm}$ was used. The argon flow was $17 \mathrm{dm}^{3} / \mathrm{min}$. The amperage was $167 \mathrm{~A}$, the arc voltage was $19.4 \mathrm{~V}$, and the welding speed was $0.732 \mathrm{~m} / \mathrm{min}$. After each pass of the torch, the waveguide on which the surfacing was carried out was freely cooled to a temperature of $21{ }^{\circ} \mathrm{C}$. Figure 11 shows a clear dependence of the appearance of the padding weld's face on the phase of the standing wave of vibrations in the surfaced waveguide.
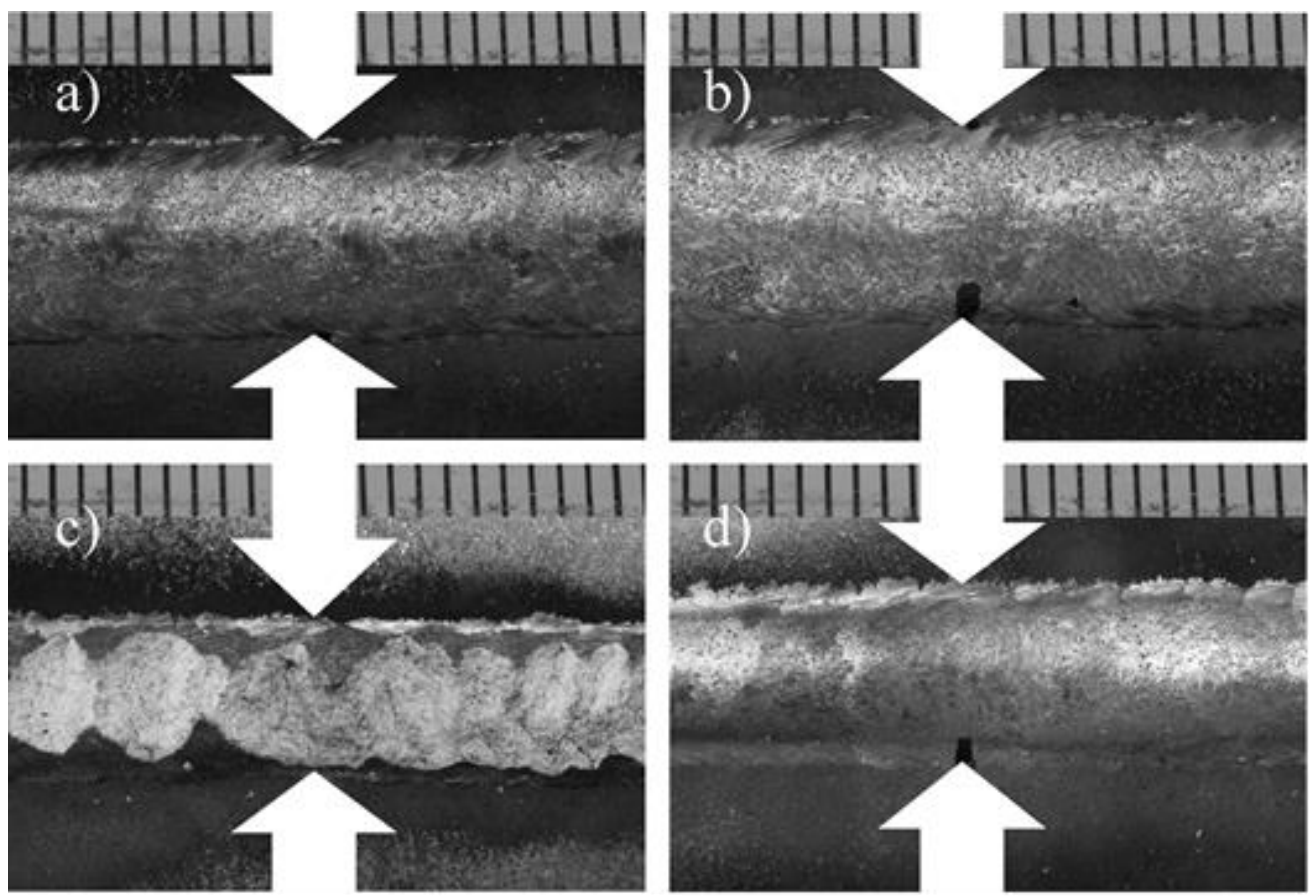

Fig. 11. View of the padding weld made by MIG method: a) without vibrations in the area of $z=0.127 \mathrm{~m}, \mathrm{~b}$ ) without vibrations in the area of $z=0.1905 \mathrm{~m}, \mathrm{c})$ with the use of ultrasonic vibrations in the area of $z=0.127 \mathrm{~m}(1 / 2 \lambda), \mathrm{d}) \mathrm{using}$ ultrasonic vibrations in the area of $z=0.1905 \mathrm{~m}(3 / 4 \lambda)$, the arrows indicate the characteristic values of the coordinate $z$ (visible scale in $\mathrm{mm}$ )

Figure 12 shows the characteristic sequences of the pool's crystallization stages in the form of lighter and darker "arcs", every few $\mu \mathrm{m}$, starting from the fusion line up to the face surface. The surface distributions of the elements showed the occurrence of alternating $\mathrm{Si}$ and $\mathrm{Cu}$ bands (Fig. 12c).

It also turned out that the shape and proportions of the dimensions of the padding welds undergo certain changes, depending on the $z$ coordinate determining the phase of introduced vibrations. Figure 13 shows these dependencies.

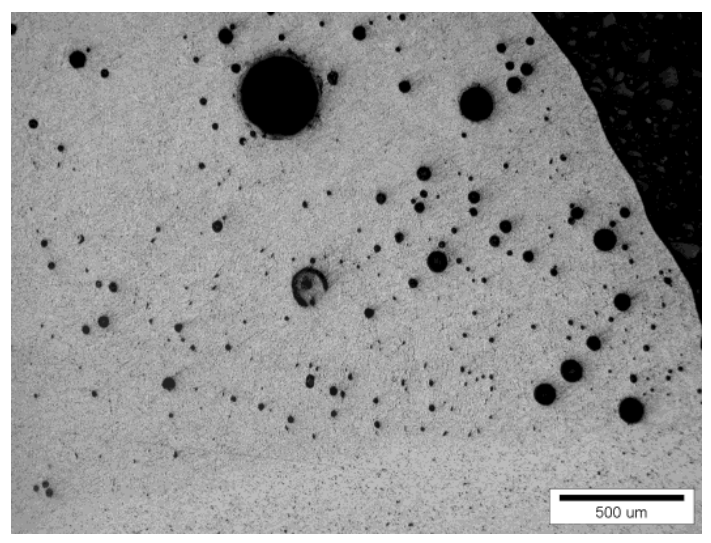

(a)

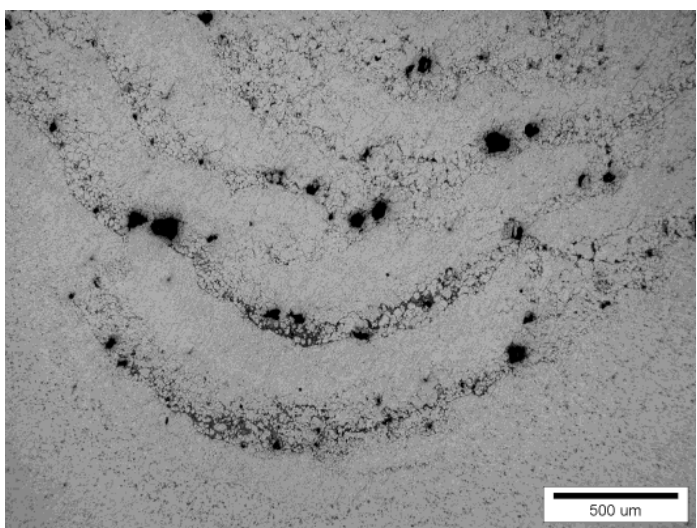

(b) 

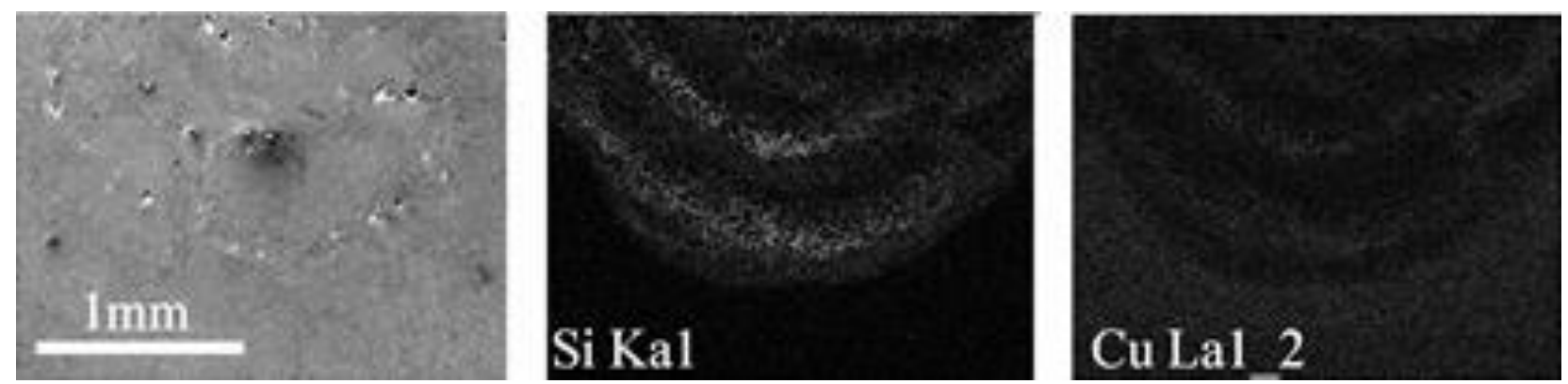

(c)

Fig. 12. Macrostructure of weld made by MIG method: (a) without ultrasonic vibrations; (b) with the use of ultrasonic vibrations $z=0.127 \mathrm{~m}(1 / 2 \lambda)$; (c) Results of tests on the distribution of $\mathrm{Si}$ and $\mathrm{Cu}$ in weld made by the MIG method with the use of vibrations $z=0.127 \mathrm{~m}$
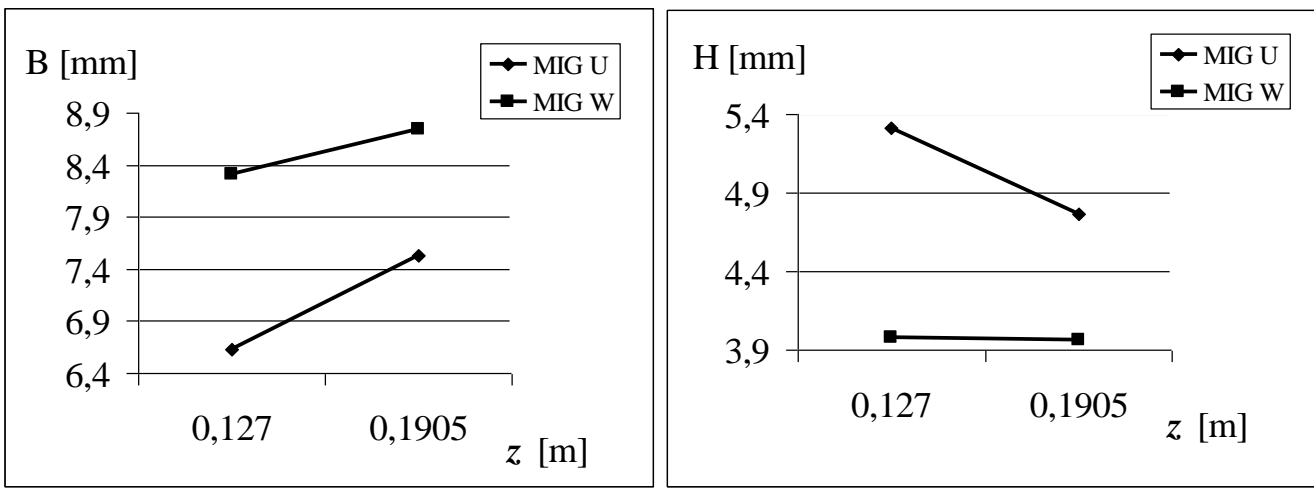

Fig. 13. The width of the face B and the depth of penetration H for MIG surfacing: U - with ultrasonic vibrations, W without vibrations

During the introduction of vibrations in the waveguide node, the penetration depth of the padding welds laid with the MIG method is significantly reduced, while the width of the face increases slightly. During the MIG surfacing with the use of vibrations in the "arrow" of the waveguide, a violation of the continuity of the mechanical face was found, and the visible significant surface oxidation was most likely caused by the disturbance of the continuity of the gas shield. Additionally, the band structure of remelting with segregation of alloy components is observed in this case.

\section{Remelting of a forming waveguide made of steel 1.0503 (45) with the use of a laser beam}

An experiment of $\mathrm{CO}_{2}$ laser remelting of a waveguide made of 1.0503 steel was carried out (45) [4]. Figure 14 shows a waveguide with characteristic dimensions for vibration "nodes" and "arrows".

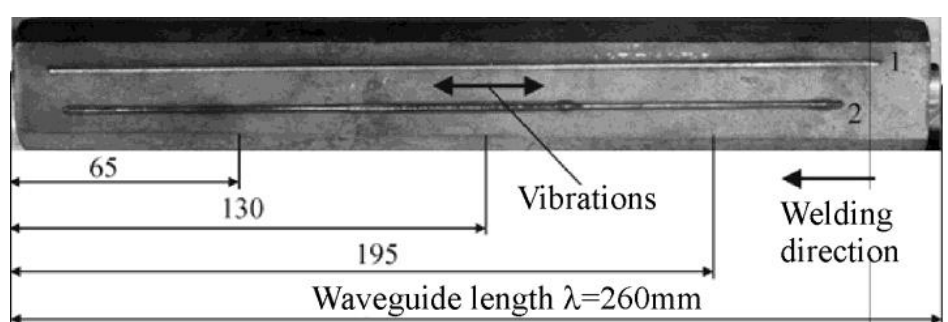

(a)

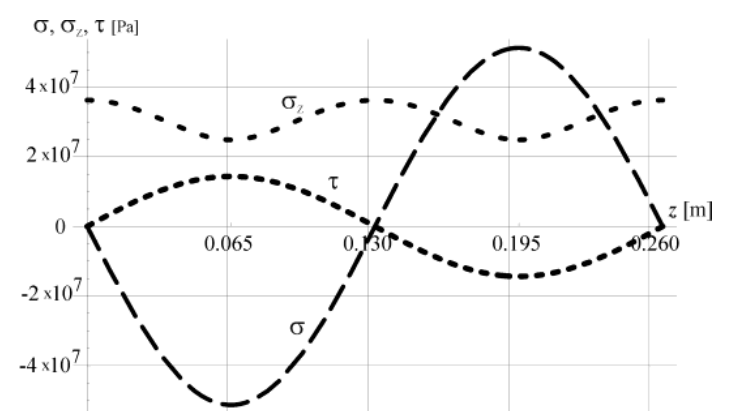

(b)

Fig. 14. View of the waveguide made of steel 1.0503 with the obtained remelting (upper no 1 without vibrations, lower no 2 with the use of ultrasonic vibrations). The arrow shows the direction of the head travel (a); distribution of axial stresses $\sigma$, transverse stresses $\tau$ and reduced $\sigma z$ in the waveguide: $z=\lambda=0.260 \mathrm{~m}$ (b)

The most advantageous and homogeneous structural structure of the remelting zone was obtained as a result of fusion assisted by high-power ultrasonic vibrations in the case of the coordinates $z=0.065 \mathrm{~m}$ and $z=0.195 \mathrm{~m}$ (Fig. 15). 
It can be seen that the parameters describing the penetration geometry clearly differ depending on the phase of the applied vibrations and whether they occur in general. The width of the face and heat affected zones of HAZ1 on the left side of the remelting and HAZ2 on the right as well as the depth of fusion change substantially from the remelting site associated with the vibration phase. In the "nodes" a decrease in these parameters is observed, and in the "arrows" an increase. The dependencies are very clear.

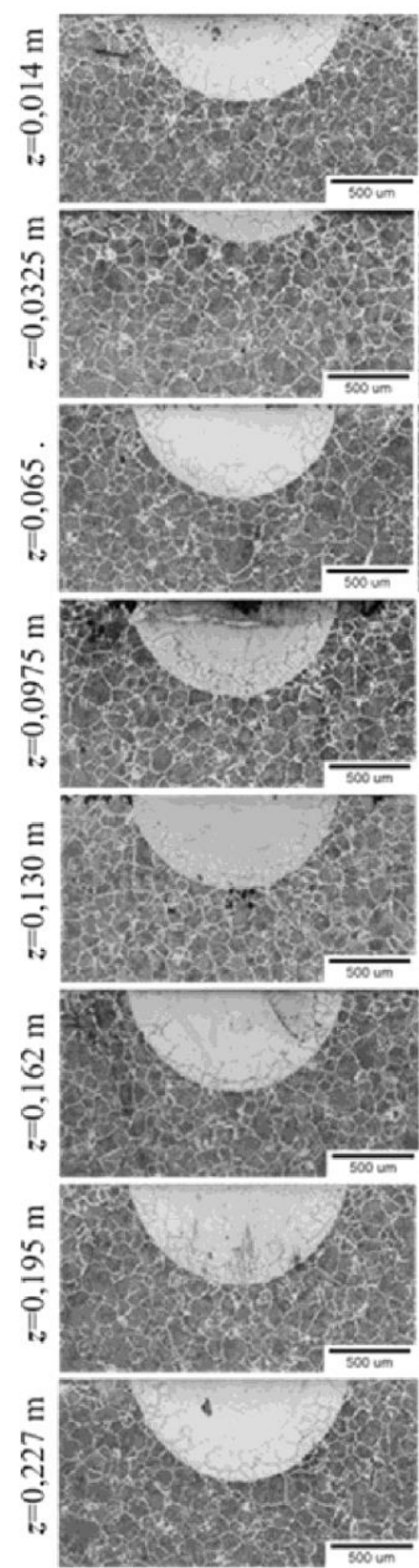

(a)
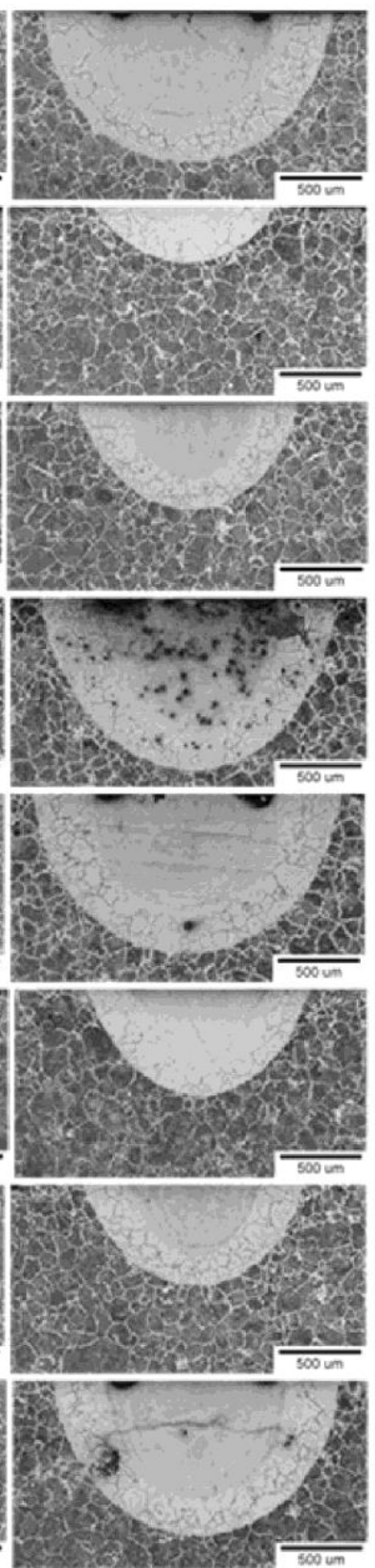

(b)

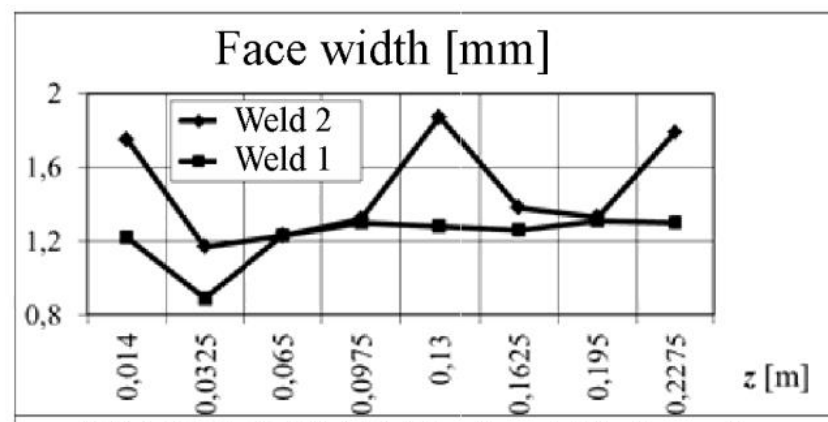

Weld No2 HAZ No 2 width [mm]
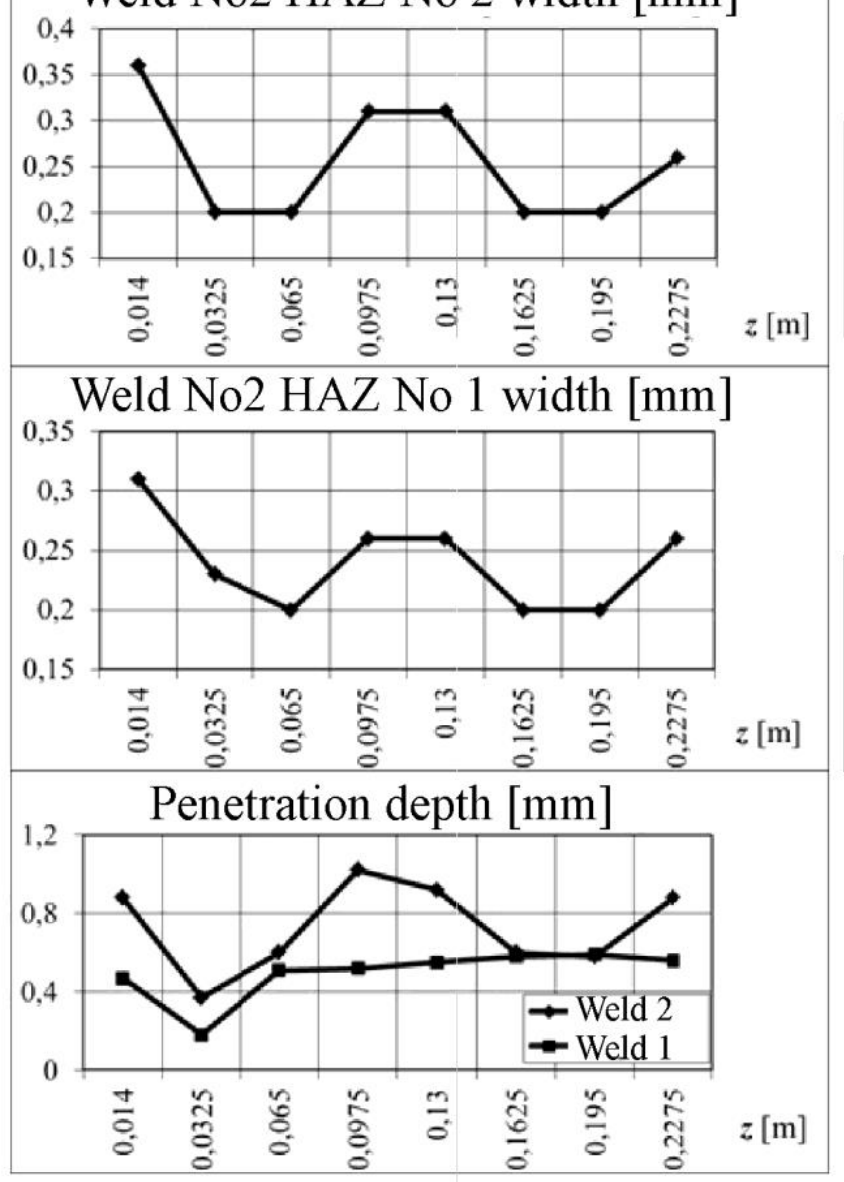

(c)

Fig. 15. Cross-sections of penetrations in steel 1.0503 made with a $\mathrm{CO}_{2}$ laser: a) fusion 1 without vibrations; b) penetration 2 with vibration; c) the penetration width and the HAZ for different values of the $z$ coordinate

\section{MAG surfacing with the introduction of stochastic vibrations}

The experimental work presented above was largely based on the use of supporting the bonding processes with vibrations of a known, unchanging frequency and amplitude. However, difficulties are associated with the direct application of these ideas in industrial conditions that require a special vibrating system and direct contact with the material. In this context, an important question arose: will the use of vibrations that do not cause such difficulties as e.g. stochastic vibrations bring about similar benefits as in the previous cases? The question is absolutely justified, but in order to check it, it was necessary to choose an effective method of introducing them into the bonding zone. The advantage of this solution is the presence of a wide spectrum of vibrations that are not characterized by a fixed phase. The choice fell on a 
simple, well-known and cheap method, which is shot blasting. This method is easy to apply in practice, as shot blasting machines are commonly used devices in the metal industry. Therefore, a MAG surfacing experiment was planned and carried out on a P235GH steel pipe with a diameter of $89 \mathrm{~mm}$, a wall thickness of $3.2 \mathrm{~mm}$ and a length of $2000 \mathrm{~mm}$ with the participation of vibrations generated by steel shot [16]. The surfacing tests were carried out in a downhand position parallel to the pipe axis (Fig. 16). Shielding gas M 21 and a wire from Oerlikon Carbofil 1 Gold (G3Si1) with a diameter of $1 \mathrm{~mm}$ were used. Padding welds were applied with the following parameters: $\mathrm{I}=100 \mathrm{~A}, \mathrm{U}=20 \mathrm{~V}$, wire feed speed $3 \mathrm{~m} / \mathrm{min}$, surfacing speed $1.5 \mathrm{~m} / \mathrm{min}$. The padding welds were obtained without the participation of mechanical vibrations and with the participation of mechanical vibrations generated in the shot-blasting process. A representative microstructure of the obtained padding welds is shown in Figure 17.

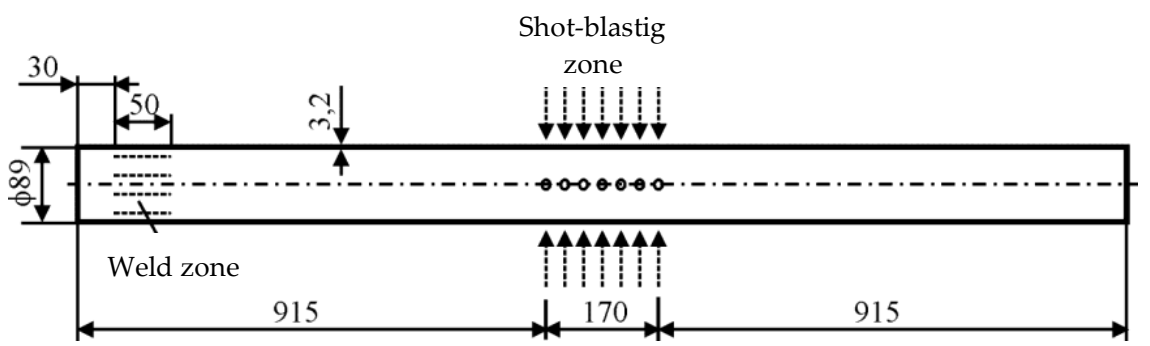

Fig. 16. Scheme of the surfacing process with the introduction of mechanical vibrations as a result of shot blasting

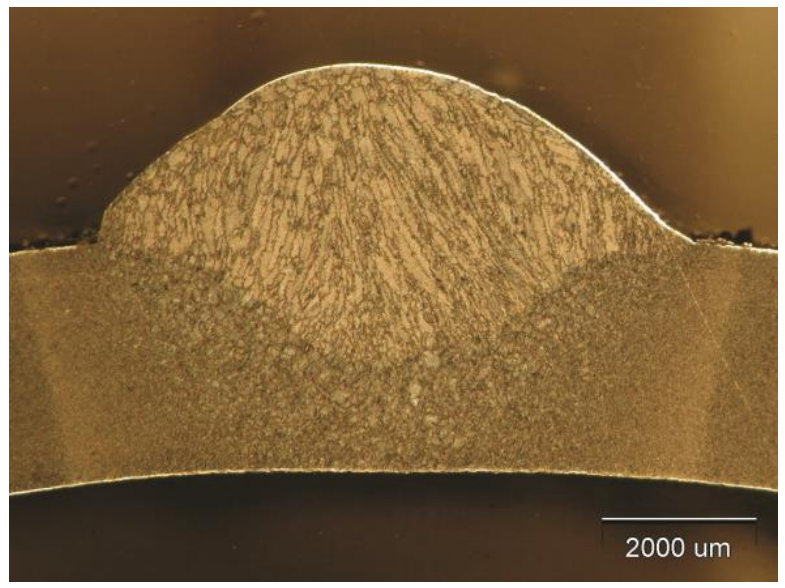

(a)

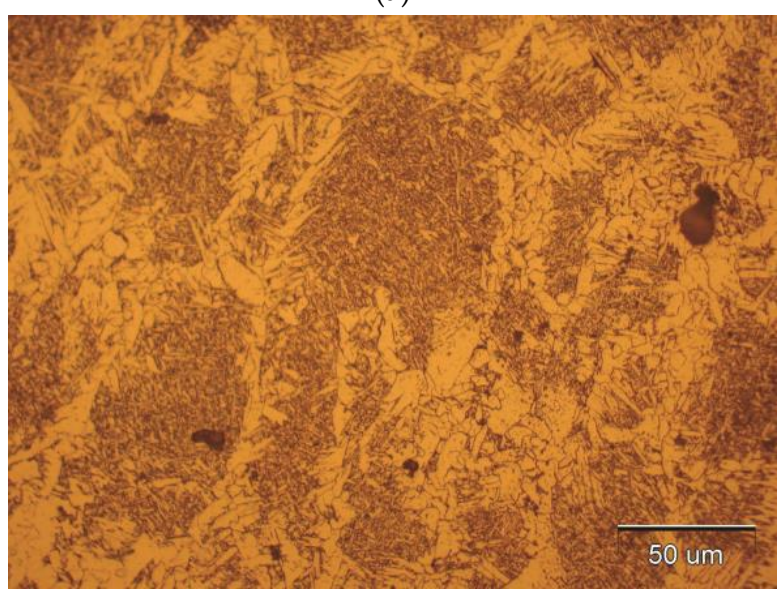

(c)

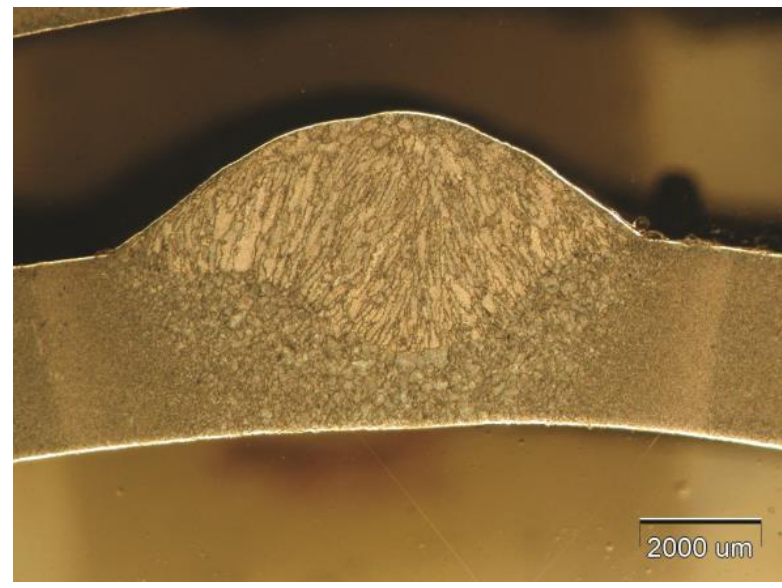

(b)

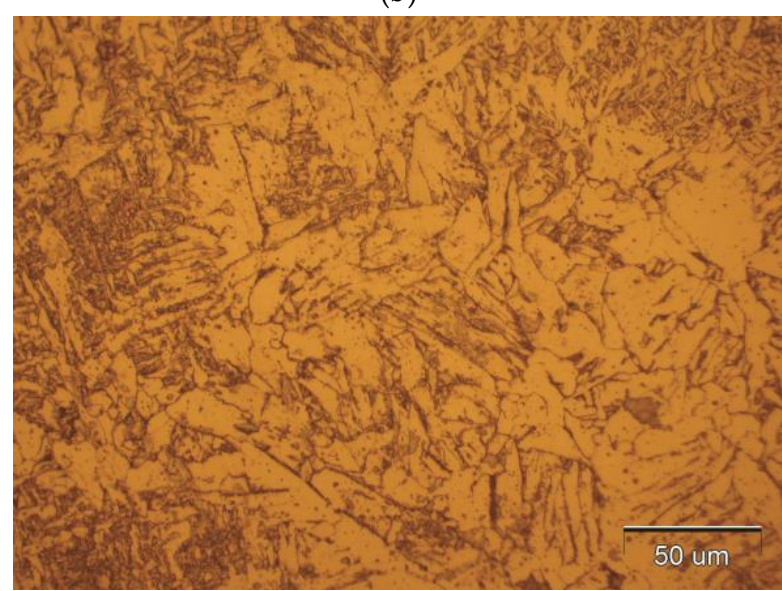

(d)

Fig. 17. Macrostructure of welds; (a) No. 1 obtained without shot blasting, (b) No. 2 obtained with shot blasting, (c) No. 1 in the area of the weld adjacent to the face, (d) No. 2 in the area of the weld adjacent to the face

Differences in the structure of the HAZ can be seen. The grains in this zone belonging to the padding weld No. 2, i.e. subjected to vibrations during surfacing, have a structure with a greater degree of evenness. In relation to the obtained surfacing welds 1 (without vibrations) and 2 (with the participation of vibrations), an analysis of the average grain size according to ASTM E112-13 was also carried out in individual areas such as the root, face, fusion line and HAZ. Representative results of this analysis are presented in Figure 18. 
On the basis of representative photos of the macrostructure (Fig. 17 a and b), the geometrical parameters of the padding welds were determined, the degree of mixing and the shape coefficient of padding welds were calculated and given in Table I. The values of these parameters are the average values of the measurements for three cross-sections obtained for the case without vibrations and with vibration.

\section{Average grain number in weld no 1 zone}

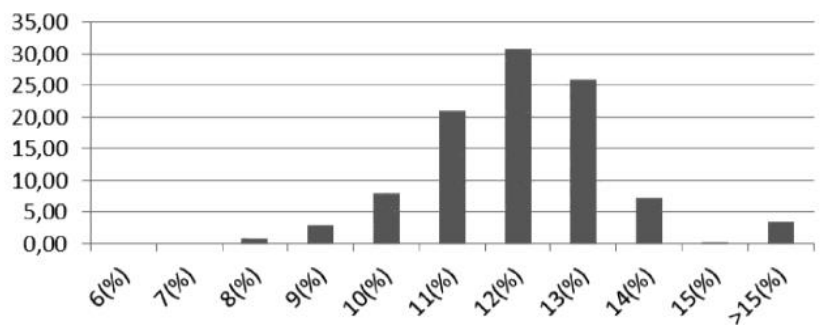

\section{Average grain number in weld no 2 zone}

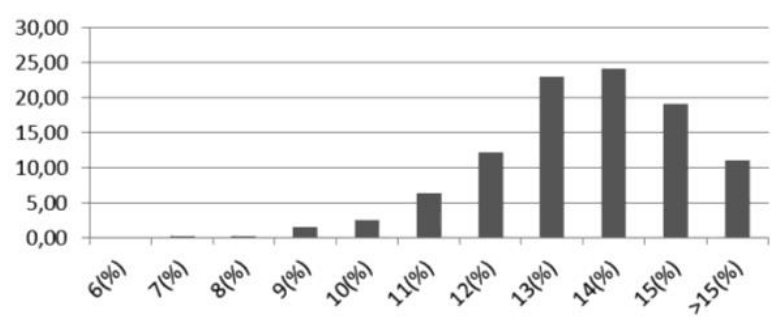

Fig. 18. The results of the grain size analysis in the area of the welds no. 1 (left) and 2 according to ASTM E 112-13

Table I. Parameters characterizing the shape of welds

\begin{tabular}{ccc}
\hline Parameter & $\begin{array}{c}\text { Padding weld } \\
\text { No. 1 }\end{array}$ & $\begin{array}{c}\text { Padding weld } \\
\text { No. 2 }\end{array}$ \\
\hline $\begin{array}{c}\text { Width of the face, } \boldsymbol{B}[\mathrm{mm}] \\
\text { Height of the padding weld, }\end{array}$ & 7,56 & 8,86 \\
$\boldsymbol{H}[\mathrm{mm}]$ & 4 & 4 \\
Shape coefficient, $\boldsymbol{B} / \mathrm{H}$ & 1,89 & 2,22 \\
Degree of mixing, $\boldsymbol{W}[\%]$ & $38 \%$ & $44 \%$ \\
\hline
\end{tabular}

HV0.1 hardness measurements were also carried out. The hardness was measured from the face towards the root. The results of microhardness measurements are presented in Figure 19. The points in the diagram represent the average values of three measurements.

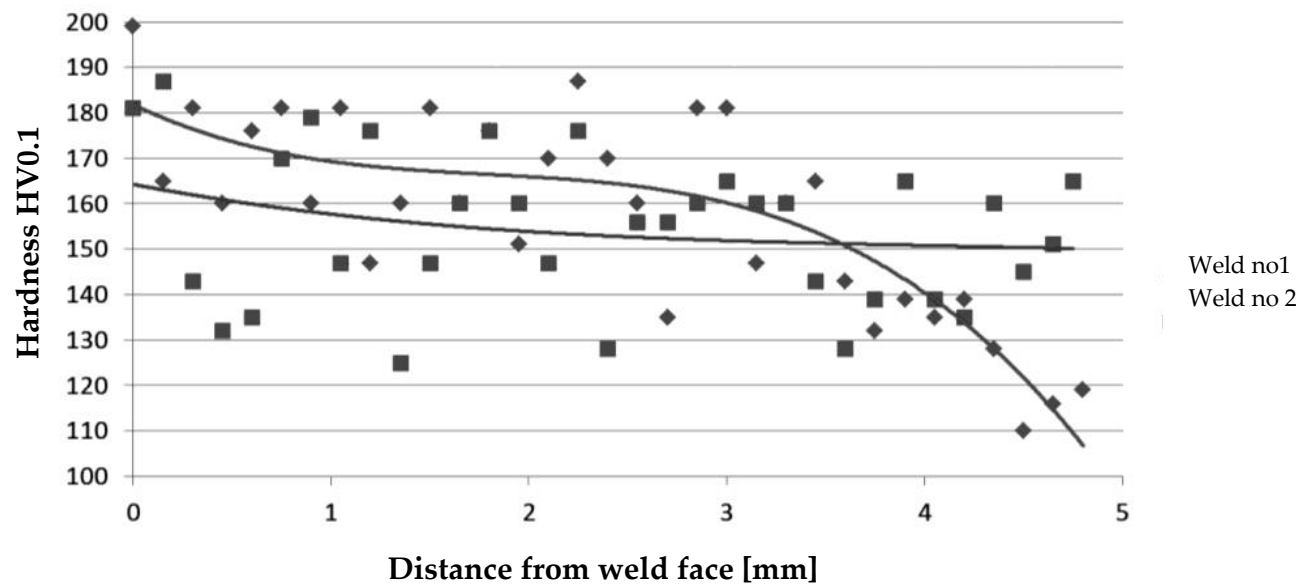

Fig. 19. Measurement results of HV 0.1 hardness along the weld axis (trend lines are marked)

The observation of the macrostructure of the obtained padding welds showed that the application of vibrations with a four-nozzle shot blasting machine during the surfacing process changed the shape of the padding weld. A wider face was created while maintaining the same height of the padding weld, and the degree of mixing in the padding weld was increased.

Photos of the microstructure made in the characteristic areas of padding welds show significant differences in their structure in relation to the padding weld obtained without vibrations and for the one with vibrations. It can be concluded that the greatest differentiation of the structure occurs in the areas of the face. This is also confirmed by the analysis of the size and distribution of grains in these zones. In the face, the disappearance of the perlite islets can be observed, which is confirmed by the reduction of the maximum grain size and the softening of the maximum concentration and shifting it towards higher percentages. 
Microhardness measurements have shown that there is a significant difference in its distribution. In the vicinity of the face, higher values were recorded than in the center of the padding weld and much higher in relation to the hardness in the root area. It is also worth noting that the hardness distribution in padding weld No. 2 obtained by shot-blasting shows a significant degree of flattening, and the average hardness value is lower by approx. 15 to 20 HV01. It is different in the case of the root. The hardness distribution trend lines of both padding welds intersect in the root area, and the hardness in padding weld No. 1 drops by approx. 50 HV01 compared to padding weld No. 2.

Both metallographic tests and microhardness measurements clearly show that the shot-blasting process caused visible structural changes and changes in the properties of the obtained padding welds. These changes can be seen as positive, both in terms of grain shape and size and in terms of homogenization

of the structure.

As a result of the described research, a thesis can be formulated that the use of shot-blasting to introduce mechanical vibrations during welding can be an effective process and is an interesting alternative to other more complicated and troublesome methods requiring constant and reliable contact of the vibrating system with the base material. The fact that the shot-blasting method is common and available may be a key factor in its effective use in industrial welding. Documented changes in the microstructure and properties of padding welds obtained on ordinary low-carbon steel may not solve any significant material problem, but prove that the shot-blasting process is worth considering as a replacement method of supporting welding processes with vibration. Nevertheless, in order for the proposed method to give more predictable and reproducible results, it still requires solving many problems related to the selection and optimization of parameters, such as the average mass of the shot particles, its average momentum value, the intensity of collisions per time unit, the range and shape of the surface of the shot blasted material. as well as its average size and distance from the welding heat source. The determination of these factors as well as the description of the vibrations they cause is becoming a priority in the development of shot blasting technology as a method of introducing mechanical vibrations in welding processes.

\section{Laser beam remelting with the support of acoustic vibrations}

Research related to the application of mechanical vibrations during welding processes shows that it is possible to achieve satisfactory results without the need to directly and securely attach the vibrating system to the base material. Vibrations can be introduced, for example, by means of pulses of a laser beam [18], controlled electric arc modulation [16] or impact methods using the transfer of mass collision energy [19]. One of such methods is described in [19]. It is interesting because the vibrations are introduced acoustically, i.e. contactlessly, and secondly, it gives a wide range of possibilities to modify the parameters characterizing mechanical vibrations such as: frequency, intensity, distance from the welding heat source. The remelting tests were carried out in a downhand position parallel to the pipe axis. The remelting was obtained without the participation of mechanical vibrations and with the participation of mechanical vibrations generated acoustically. A Wegmann-Baasel VFA 2500 type VFA $2500 \mathrm{CO}_{2}$ laser with a power of $2500 \mathrm{~W}$ and a wavelength of $10.6 \mu \mathrm{m}$ was used for remelting. A mixture of $\mathrm{CO}_{2}, \mathrm{~N}_{2}$ and He gases was used as protection. The result was linear remelting with a length of approx. $150 \mathrm{~mm}$ arranged parallel to the pipe axis on its outer surface: remelting No. 1 - with vibrations of $50 \mathrm{~Hz}$ introduced transversely to the axis and perpendicular to the pipe surface, remelting No. 2 - with vibrations of $50 \mathrm{~Hz}$ introduced along the pipe axis into its interior, remelting No. 3 - with vibrations with a frequency of $1385 \mathrm{~Hz}$ introduced into its interior along the pipe axis, remelting No. 4 - remelting without vibrations and remelting No. 5 - with vibrations of $110 \mathrm{~Hz}$ introduced along the pipe axis to its interior. After performing the experimental remelting tests, five linear penetrations were obtained, which were subjected to comparative metallographic tests and Vickers microhardness measurements at a load of $100 \mathrm{G}$. To generate acoustic vibrations, a Bruel \& Kjaer type 1023 sinusoidal generator with an amplifier type 2734 and a Bruel \& Kjaer type 4295 horn speaker with high intensity and variable frequency were used. A Bruel \& Kjaer type 2236 meter was used to measure the intensity of acoustic vibrations. A constant intensity of acoustic vibrations of approx. $100 \mathrm{~dB}$ was used for the remelting tests.

The metallographic photos of the remelting allowed to assess the width of the face $B$, the depth of the fusion $\mathrm{H}$, and made it possible to calculate the shape coefficient $\mathrm{B} / \mathrm{H}$. All the above-mentioned geometric features were determined on the basis of three samples obtained with a specific set of technological parameters and presented in Figure 21. 


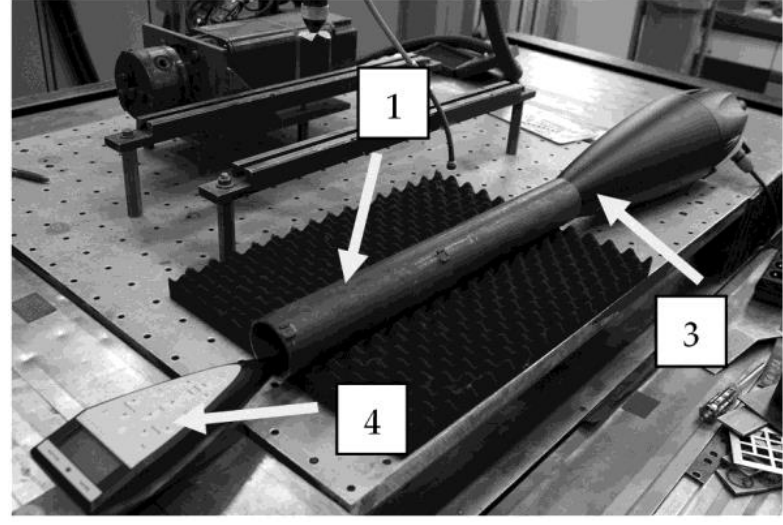

(a)

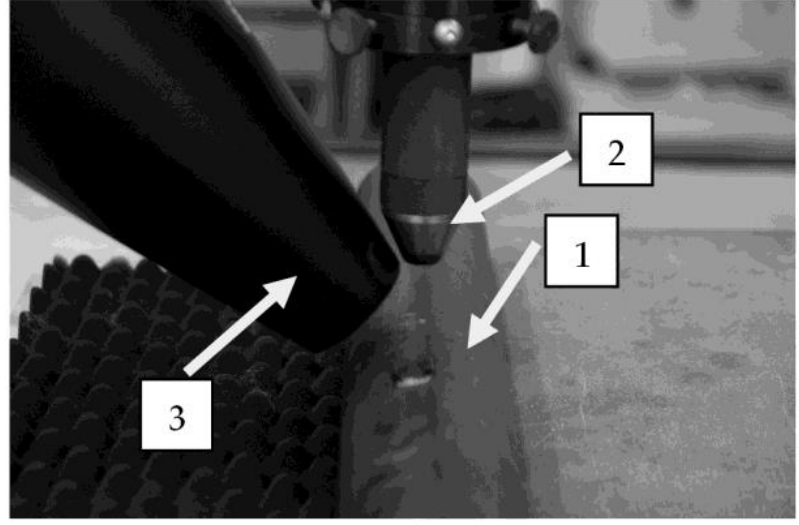

(b)

Fig. 20. Introducing acoustic vibrations transversely to the pipe axis (a), parallel to pipe interior (b): 1 - pipe, 2 - laser head, 3 - horn speaker, 4 - Bruel \& Kjaer vibration intensity meter type 2236
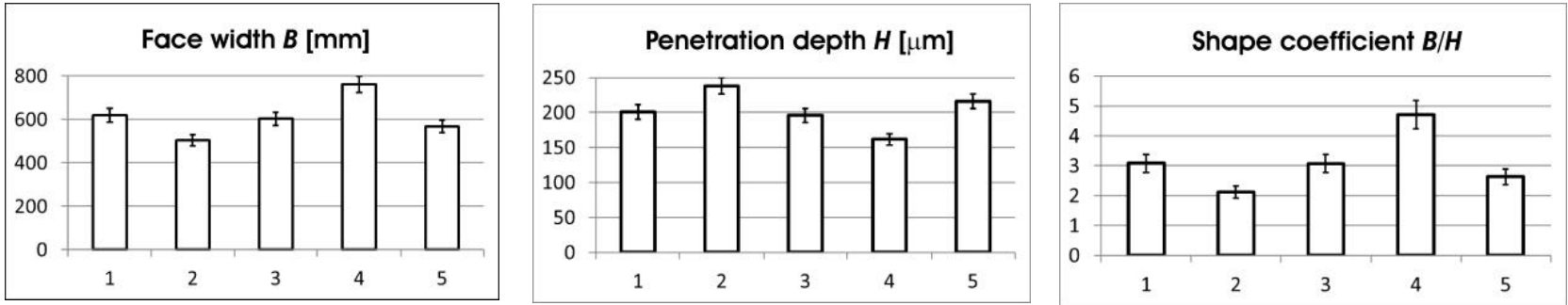

Fig. 21. Shape coefficients: face width $B$, fusion depth $H$, shape coefficient $B / H$
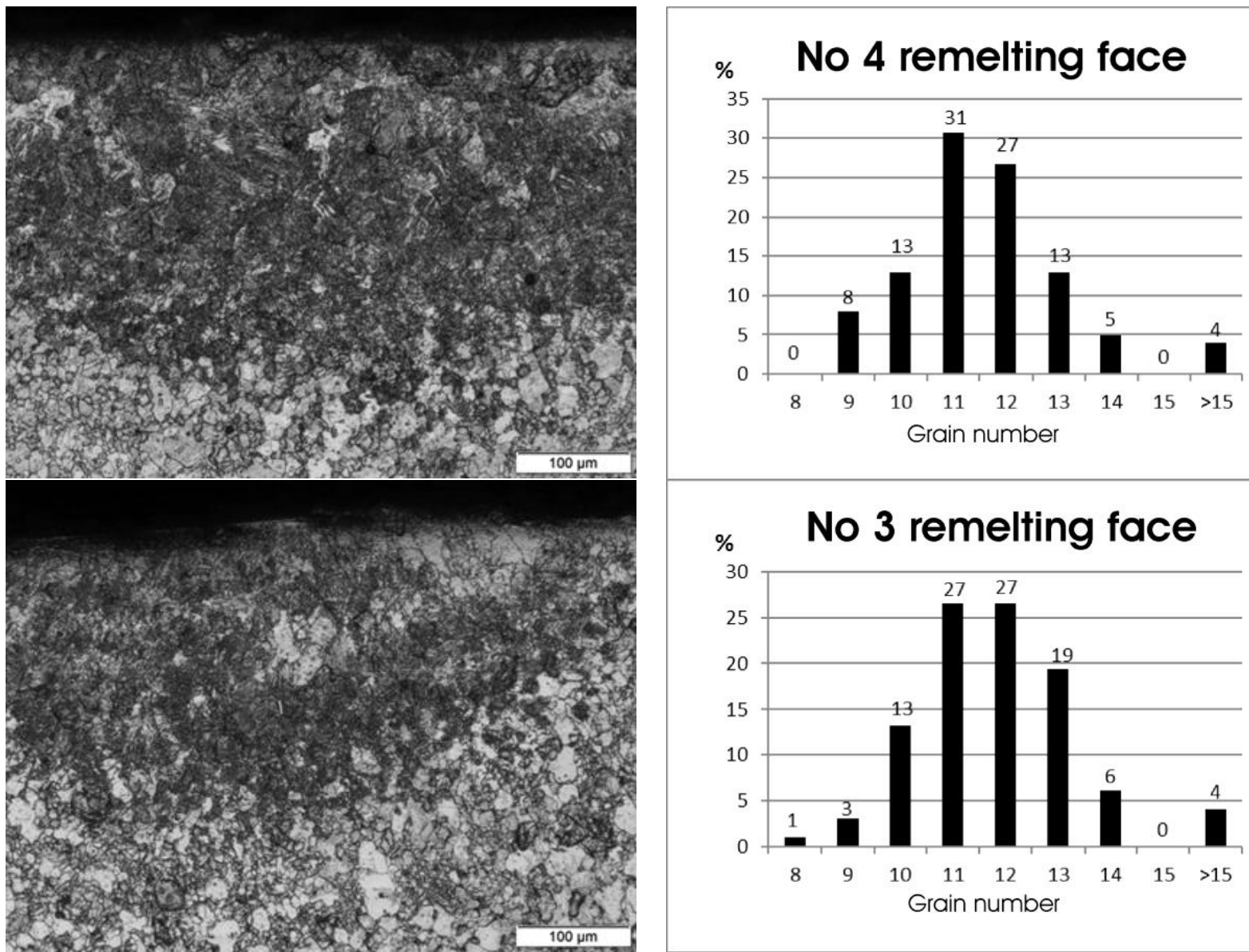

Fig. 22. Representative images of the structure and the results of grain size analysis for the obtained remelting from the $105 / 90 \mu \mathrm{m}$ area near the face. Remelting No. 4 obtained without vibrations, No. 3 with acoustic vibrations with a resonance frequency of $1385 \mathrm{~Hz}$ 
Hardness measurements were made on the cross-sections of the remelting parallel and perpendicular to the face. The obtained results are shown in Figure 23. In the case of remelting No. 4 - obtained without vibration support in the heat-affected zone, increased hardness values can be noticed at a depth of $50 \mu \mathrm{m}$ (approx. $250 \mathrm{HV} 0.1$. The hardness measurement results along the remelting axis at a depth of approx. $100 \mu \mathrm{m}$ show the value of $300 \mathrm{HV} 0.1$.
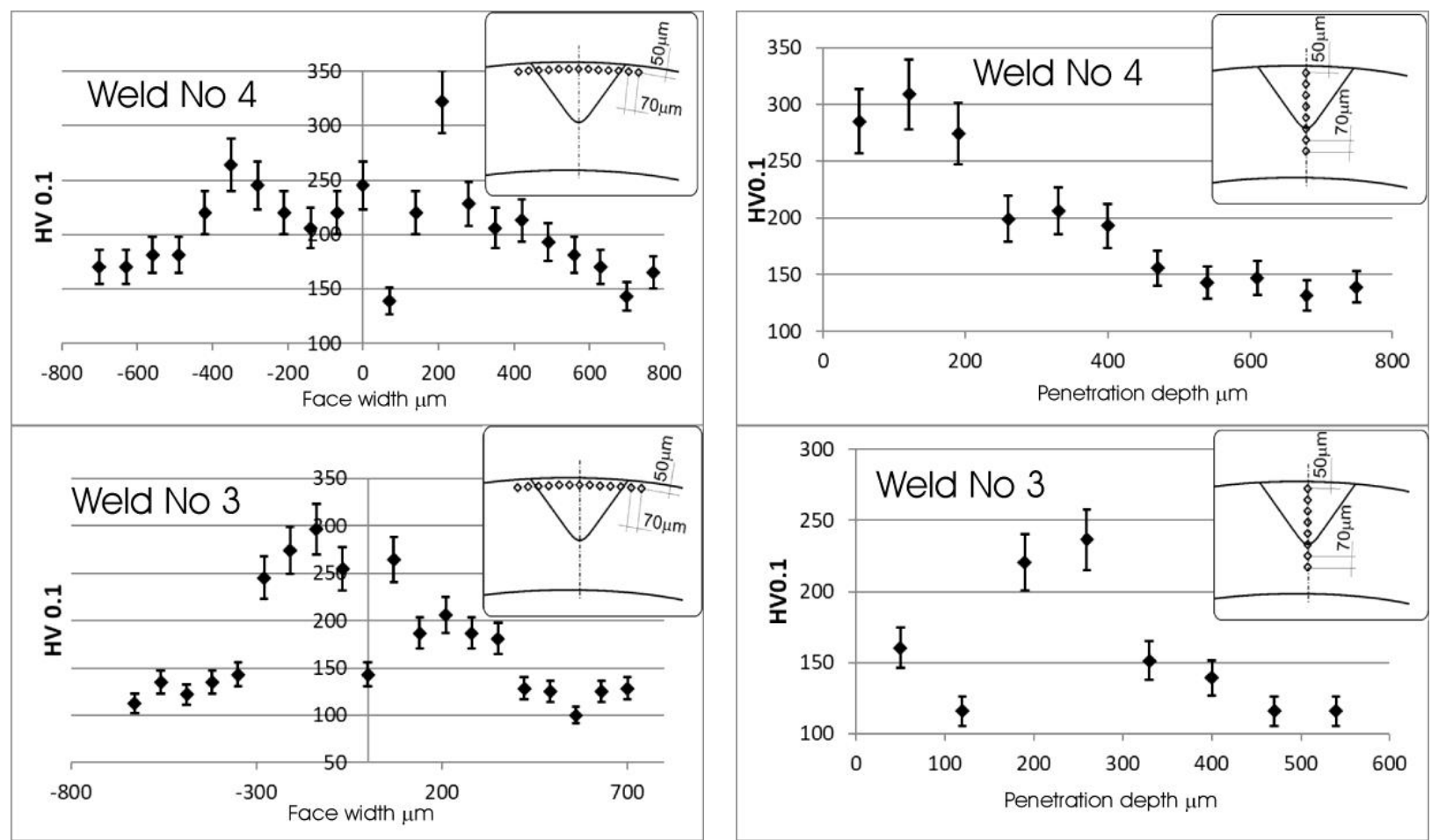

Fig. 23. Distribution of hardness: near the face and in the centre of remelting no. 4 and 3

Remelting No. 3, obtained with the assistance of acoustic vibrations with a resonance frequency of $1385 \mathrm{~Hz}$ introduced longitudinally into the pipe interior, in the analogous area close to the face, showed respectively lower values of approx. 300 HV0.1 and approx. 160 HV0.1. Along the axis, at a depth of $120 \mu \mathrm{m}$, the hardness reached approx. 110 HV0.1 and at a depth of approx. $200 \mu \mathrm{m}$ it reached 245 HV0.1.

The presented results of laser remelting with the participation of acoustic vibrations show that they can affect both the geometry of the weld and the microstructure. The scale of these changes is small with the effects obtained by other methods that directly introduce vibrations $[4,15,20]$, but it makes it possible to achieve constant conditions at the welding site using non-contact vibrations transmitted only in gas, as is the case in [19]. It is worth mentioning that the maximum depth of penetration and, at the same time, the minimum width of the face were obtained in the case of a weld subjected to $50 \mathrm{~Hz}$ vibrations propagating axially inside the pipe (remelting No. 2). The reasons can be found in the transverse stresses generated by the cyclical change of the sound pressure inside the pipe. The grain size decreased the most due to vibrations of $50 \mathrm{~Hz}$, propagating along the pipe axis (remelting No. 2). The smallest grains were observed in the case of longitudinal introduction of acoustic vibrations with a frequency of $110 \mathrm{~Hz}$.

Hardness measurements showed that the longitudinal introduction of acoustic vibrations generally reduced the hardness value (by approx. 50 HV0.1) in the heat affected zone, regardless of the vibration frequency used. At the resonance frequency of $1385 \mathrm{~Hz}$, the decrease in hardness in relation to the weld obtained without vibrations was small and amounted to approx. 25 HV0.1. When transverse acoustic vibrations were applied, the hardness also decreased by approx. $50 \mathrm{HV} 0.1$, but by $200 \mu \mathrm{m}$ below the face surface it increased to $350 \mathrm{HV} 0.1$. This may indicate a deep shift in the equipotential surface associated with the heat affected zone. The greatest changes in the structure obtained in the area of the face are caused by acoustic vibrations with a resonance frequency. The fragmentation of the structure, on the other hand, can be achieved by introducing vibrations longitudinally inside the pipe, which is possible due to the uniform transverse stresses in the base material of the pipe. According to the authors [21], who used vibrations with a frequency of 150 to $300 \mathrm{~Hz}$, the main influence on changes in mechanical properties is their frequency. Another very important issue is the problem of oscillation of the molten metal pool formed during laser beam remelting. Due to the fact that no tests were carried out on the vibrations of the melt pool, in this case it is definitely worth referring to what the available publications write on this subject. 
In one of the articles [22] model experiments and their comparison were carried out. It was found that the most common weld pool oscillations during laser welding are in the range of 500 to $3500 \mathrm{~Hz}$, depending on the radius of the laser beam and the absorbed laser power.

In another publication [23] it was mentioned that the vibration frequency of the pool was greater than $1 \mathrm{kHz}$. In yet another publication [24], the vibration frequency of the pool is determined to be close to the value of $200 \mathrm{~Hz}$.

In future research, it is worthwhile to analyze numerically, analytically or experimentally the natural frequency of the pool vibrations for a given TEM variation, power, velocity and beam diameter, also taking into account other important parameters such as gas flow, material factors, etc. These are issues that are foreseen for the future and will likely be in a separate publication.

\section{Summary}

The article presents an overview of selected issues related to the support of various bonding processes with mechanical vibrations. Research on the influence of vibrations in bonding processes focused on the methods of their conduction, the direction of propagation, form and frequency, based on several joining methods and many basic materials. There were many fundamental variables over the years of research (from 1992 to the present), but it is possible to formulate basic achievements in this area:

- appropriate application of vibrations may have a positive effect on the improvement of the structure and mechanical properties of fused and non-fused areas, regardless of the types of vibrations,

- the positive impact of various types of vibrations introduced into the bonding zone may take place by using various bonding methods,

- the use of mechanical vibrations as a factor supporting the bonding processes can have a positive effect on many metallic base materials,

- characterization of the assisted bonding zones by means of vibrations, which took place at the level of microscopic tests, SEM and measurements of mechanical properties, showed the effectiveness of vibrations in relation to the requirements and expectations regarding the reduction of grain size and causing their even-axis structure, reduction of hardness in the sensitive heat-affected zone and increasing strength.

Based on the obtained results, it is planned to focus research on supporting the processes of bonding with vibrations towards other basic materials, e.g. difficult-to-weld alloy steels and selected light alloys. It is also worth dealing with the aspect of precise determination of vibration parameters and methods of their introduction so as to become independent of the variable distance of the welding heat source from the vibration source. In the near future, special emphasis will be placed on the research being a continuation of the work [16, 19], while in the long term it is planned to support the coating application processes with mechanical vibrations.

Author Contributions: Conceptualization, A.K.; methodology, AK. and P.C., J.G., P.K.; software, K.K; validation, A.K. and P.K.; formal analysis, A.K.; investigation, A.K. and P.K.; resources, A.K.; data curation, A.K.; writing - original draft preparation, A.K.; writing - review and editing, A.K.; visualization, A.K and P.K.; supervision, J.G.; project administration A.K.

Funding: This research received no external funding

Conflicts of Interest: The authors declare no conflict of interest.

\section{References}

[1] Momot A., Intensyfikacja procesu zgrzewania dyfuzyjnego za pomocą drgań ultradźwiękowych, praca dyplomowa magisterska, promotor: dr inż. Pikor N., konsultacje: Krajewski A., Zakład Inżynierii Spajania, Politechnika Warszawska, Warszawa, 1992

[2] Olesińska W., Krajewski A., Brazing of alumina to steel using ultrasonic intensification, Proceedings of the EUROMAT'97 5th European Conference on Advanced Materials and Processes and Applications, vol. 2, 661664, Maastricht, 1997

[3] Krajewski A. Cegielski P., Hudycz M., Kolasa A., Skrzyniecki K., Nakładanie powłok i spajanie z wykorzystaniem pulsacyjnego mikrozgrzewania oporowego, Przeglad Spawalnictwa, 2009, Vol. 80(11), 73-77.

[4] Krajewski A., Wpływ drgań mechanicznych wykorzystywanych w procesach spajania na właściwości połączeń, Prace naukowe Politechniki Warszawskiej, Rozprawa habilitacyjna, zeszyt 258, Oficyna Wydawnicza Politechniki Warszawskiej, 202 s., ISBN 978-83-7814-118-1 
[5] Olesińska W., Krajewski A., grant KBN 7S20100605, 1997

[6] Weite W., Influence of vibration frequency on solidification of weldments, Scripta mater. 42, pp. 661-665, 2000

[7] Devine J., Ultrasonic Welding Plays Key Role in Photovoltaic Cell Assembly, Welding Journal, 2007, Vol. 86, 52, 2007.

[8] Evans A. G., Bartlett A., Davis J. B., Flinn B. D., Turner M., Reimanis I. E., The fracture resistance of metal/ceramic/intermetallic interfaces, Scripta Metallurgica et Materialia, 1991, Vol. 25(5), 1003-1010, https://doi.org/10.1016/0956-716X(91)90492-J

[9] Watanabe T., Shiroki M., Yanagisawa A., Sasaki T., Improvement of mechanical properties of ferritic stainless steel weld metal by ultrasonic vibration, Journal of Materials Processing Technology, Niigata, Japan 27 May 2010, https://doi.org/10.1016/j.jmatprotec.2010.05.015

[10] Krajewski A., Wspomaganie procesów spawalniczych drganiami mechanicznymi, Zeszyt Naukowy nr 229, s. 33-51 (seria Mechanika), ISSN 0137-2335, pt. Innowacje w technikach spajania, Oficyna Wydawnicza Politechniki Warszawskiej, 2009

[11] Cegielski P., Hudycz M., Kolasa A., Krajewski A., Skrzyniecki K., Zastosowanie wirtualnych przyrządów pomiarowych do badania urządzeń i procesów spawalniczych, Zeszyt Naukowy nr 229 s. 115-124 (seria Mechanika), ISSN 0137-2335, pt. Innowacje w technikach spajania, Oficyna Wydawnicza Politechniki Warszawskiej, 2009

[12] . Krajewski A., Badanie wpływu pola ultradźwiękowego na budowę i własności struktur spawalniczych, Zeszyt Naukowy nr 230 s. 71-82 (seria Mechanika), ISSN 0137-2335, pt. Spajanie materiałów we współczesnej technice, Oficyna Wydawnicza Politechniki Warszawskiej, 2010

[13] Krajewski A., Drgania mechaniczne w procesach spawalniczych, Przeglad Spawalnictwa, 2011, Vol. 82(6), 37-42. https://doi.org/10.26628/wtr.v83i6.582

[14] Krajewski A., Wpływ fazy drgań ultradźwiękowych na strukturę i twardość napoin stopu aluminium 2017A, Przeglad Spawalnictwa, 2013, Vol. 85(1), 61-66. https://doi.org/10.26628/ps.v85i1.288

[15] Krajewski A., Włosiński W., Chmielewski T., Kołodziejczak P., Ultrasonic-vibration assisted arc-welding of aluminum alloys, Bulletin of the Polish Academy of Science, 2012, vol.60(4), 841-852. https://doi.org/10.2478/v10175012-0098-2

[16] Krajewski, A.; Kołodziejczak, P.; Wang, X., Impact of mechanical vibrations introduced by up blasting on the structure and hardness of welds on P235GH steel during MAG welding process. Weld. Technol. Rev., 2020, Vol. 91(12), 25-32. https://doi.org/10.26628/wtr.v91i12.1079

[17] Wuenschell, J. K., Helvajian, H., Enhanced laser crystallization of thin film amorphous molybdenum disulfide (MoS2) by means of pulsed laser ultrasound, Optics Express, 2019, Vol. 27(4). https://doi.org/10.1364/OE.27.005859

[18] Chen C, Fan C, Cai X, Lin S, Yang C, Analysis of droplet transfer, weld formation and microstructure in Al-Cu alloy bead welding joint with pulsed ultrasonic-GMAW method, Journal of Materials Processing Tech. 2019, https://doi.org/10.1016/j.jmatprotec.2019.03.030

[19] Krajewski A., Klekot G., Cybulak M., Kołodziejczak P., A novel method of supporting the laser welding process with mechanical acoustic vibrations, Materials, 2020, Vol. 13(18,) 1-18. https://doi.org/10.3390/ma13184179

[20] Tarasov, S. Y.; Vorontsov, A. V.; Fortuna, S. V.; Rubtsov, V. E.; Krasnoveikin, V. A.; Kolubaev, E. A., Ultrasonicassisted laser welding on AISI 321 stainless steel. Weld. World, 2019, 63, 875-886, https://doi.org/10.1007/s40194019-00716-1

[21] Singh, P. K.; Kumar, S. D.; Patel D.; Prasad, S. B., Optimization of vibratory welding process parameters using response surface methodology. J. Mech. Sci. Technol. 2017, 31, 2487-2495, https://doi.org/10.1007/s12206-0170446-0

[22] Klein, T.; Vicanek, M.; Simon, G., Forced oscillations of the keyhole in penetration laser beam welding. J. Phys. D Appl. Phys. 1996, Vol. 29, 322-332, https://doi.org/10.1088/0022-3727/29/2/008

[23] Semak, V.V.; A Hopkins, J.; McCay, M.H.; McCay, T.D., Melt pool dynamics during laser welding. J. Phys. D Appl. Phys. 1995, Vol. 28, 2443-2450, https://doi.org/10.1088/0022-3727/28/12/008

[24] Courtois, M.; Carin, M.; Le Masson, P.; Gaied, S.; Balabane, M., A complete model of keyhole and melt pool dynamics to analyze instabilities and collapse during laser welding. J. Laser Appl. 2014, Vol. 26, 042001, https://doi.org/10.2351/1.4886835

(C) 2021 by the authors. Submitted for possible open access publication under the terms and conditions of the Creative Commons Attribution (CC BY) license (http://creativecommons.org/licenses/by/4.0/). 